\title{
The British Lower Palaeolithic of the early Middle Pleistocene
}

Article

Accepted Version

Hosfield, R. (2011) The British Lower Palaeolithic of the early Middle Pleistocene. Quaternary Science Reviews, 30 (11-12). pp. 1486-1510. ISSN 0277-3791 doi:

https://doi.org/10.1016/j.quascirev.2010.02.026 Available at https://centaur.reading.ac.uk/20910/

It is advisable to refer to the publisher's version if you intend to cite from the work. See Guidance on citing.

To link to this article DOI: http://dx.doi.org/10.1016/j.quascirev.2010.02.026

Publisher: Elsevier

All outputs in CentAUR are protected by Intellectual Property Rights law, including copyright law. Copyright and IPR is retained by the creators or other copyright holders. Terms and conditions for use of this material are defined in the End User Agreement.

\section{www.reading.ac.uk/centaur}

\section{CentAUR}

Central Archive at the University of Reading

Reading's research outputs online 


\section{Author's Original Manuscript - Postprint}

This is an Author's Accepted Manuscript (text only) of an article published as: Hosfield, R. 2011. The British Lower Palaeolithic of the early Middle Pleistocene. In. J.S. Carrión, J. Rose \& C. Stringer (eds.) Ecological Scenarios for Human Evolution during the Early and Early Middle Pleistocene in the Western Palaeoarctic (Quaternary Science Reviews Special Issue): 1486-1510. 
Title: The British Lower Palaeolithic of the early Middle Pleistocene

Author: Dr Robert Hosfield ${ }^{\mathrm{a}}$

aDepartment of Archaeology, School of Human \& Environmental Sciences, University of Reading, Whiteknights, Reading, RG6 6AB, UK; E-mail: r.hosfield@rdg.ac.uk

Corresponding Author: Dr Robert Hosfield ${ }^{a}$

Department of Archaeology, School of Human \& Environmental Sciences, University of Reading, Whiteknights, Reading, RG6 6AB, UK; E-mail: r.hosfield@rdg.ac.uk; +44(0)118 3787632 (tel.); $+44(0) 1183786718$ (fax)

\section{Abstract}

The archaeology of Britain during the early Middle Pleistocene (MIS 19-12) is represented by a number of key sites across eastern and southern England. These sites include Pakefield, Happisburgh 1, High Lodge, Warren Hill, Waverley Wood, Boxgrove, Kent's Cavern, and Westburysub-Mendip, alongside a 'background scatter' lithic record associated with the principal river systems (Bytham, pre-diversion Thames, and Solent) and raised beaches (Westbourne-Arundel). Hominin behaviour can be characterised in terms of: preferences for temperate or cool temperate climates and open/woodland mosaic habitats (indicated by mammalian fauna, mollusca, insects, and sediments); a biface-dominated material culture characterised by technological diversity, although with accompanying evidence for distinctive core and flake (Pakefield) and flake tool (High Lodge) assemblages; probable direct hunting-based subsistence strategies (with a focus upon large mammal fauna); and generally locally-focused spatial and landscape behaviours (principally indicated by raw material sources data), although with some evidence of dynamic, mobile and structured technological systems. The British data continues to support a 'modified short chronology' to the north of the Alps and the Pyrenees, with highly sporadic evidence for a hominin presence prior to 500-600kya, although the ages of key assemblages are subject to ongoing debates regarding the chronology of the Bytham river terraces and the early Middle Pleistocene glaciations of East Anglia.

Keywords: Lower Palaeolithic, early Middle Pleistocene, MIS 19-12, southern Britain, temperate/cooltemperate habitats, direct hunting, biface variability, local landscapes 
1. Introduction

Reviewing the archaeological record for the British early Middle Pleistocene (MIS 19-12) is timely in light of the numerous European discoveries and chronological shifts of the last two decades, which have challenged aspects of the 'short chronology' of Roebroeks and van Kolfschoten (1994). The short chronology's claim that the first unambiguous traces of a European hominin presence dated to around 500kya was rapidly refuted by the evidence from Atapuerca TD6 (Carbonell et al., 1995), and more recently by other finds and/or revised dating from the Spanish and Italian peninsulas (Carbonell and Rodriguez, 2006; Peretto, 2006; Carbonell et al., 2008; Scott and Gibert, 2009). However recent finds from Britain and France (Parfitt et al., 2005; Despriée et al., 2006; Voinchet et al., in press) have also begun to challenge the longer-standing argument (described here as the 'modified short chronology'; Dennell and Roebroeks, 1996; Roebroeks, 2001, 2006) that the first unambiguous hominin evidence to the north of the Alps and the Pyrenees was restricted to the post-500 to 600kya period. While the earliest archaeological evidence from Britain (Pakefield) at c. 700kya may well reinforce the modified short chronology's ecological signal due to the inferred Mediterranean-type climate (Parfitt et al., 2005; Candy et al., 2006; Roebroeks, 2006), the evaluation of the remaining early Middle Pleistocene archaeology is particularly important in light of the notable increase in hominin encephalisation around 600kya, associated with Homo heidelbergensis (Gamble, 2009, Fig. 2). Both Gamble (2009) and Roebroeks (2001) have argued that the post-500kya hominin expansion in Europe, especially northern Europe, involved encephalisation and associated increases in social cognition skills and effective group sizes. Gamble (2009) has emphasised the benefits of larger community sizes in terms of co-operation in subsistence and predator defence, combined with the potential for extended fission-fusion strategies, while Roebroeks (2001) highlighted the implications of brain growth and the need for high quality foods upon subsistence strategies (co-operative hunting of large mammals), male/female relationships, and the wider social contexts of hunting (food exchange, risk sharing, and knowledge transmission). Where such behavioural repertoires present, in whole or in part, amongst those hominins present in the northern latitudes of Europe during the early Middle Pleistocene, and what are their likely 'first appearance dates'?

The British archaeological data from the early Middle Pleistocene therefore provides a valuable test case to explore the nature of hominin behaviour during this critical period in Middle Pleistocene hominin evolution. That the British record is appropriate for such questions is a result both of its long history of research and the provision of a rich chronological, climatic and environmental framework (after Roebroeks, 2006). Within this framework, research over the last twenty-five years has revealed that the MIS 19-12 period in Britain is characterised by a rich and geographically diverse archaeological record (Table 1). This paper's goal is to provide an overview of the key archaeological materials, followed by an exploration of four behavioural themes (climatic and habitat preferences; subsistence behaviours; material culture variability and patterning; and spatial and landscape behaviours) with reference to the models and predictions of Roebroeks $(2001,2006)$ and Gamble (2009). For comprehensive site-by-site and findspot-by-findspot reviews, see the key site and landscape monographs (Campbell and Sampson, 1971; Ashton et al., 1992a; Andrews et al., 1999; Roberts and Parfitt, 1999; Roberts and Pope, in press) and papers (Wymer et al., 1991; Shotton et al., 1993; Bridgland et al., 1995; Cook and Jacobi, 1998; Parfitt et al., 2005; Proctor et al., 2005; Keen et al., 2006; Ashton et al., 2008; Parfitt, 2008; Pope et al., 2009), and regional and national overviews (Roe, 1968, 1981; Woodcock, 1981; Wymer, 1985, 1988, 1999; Wessex Archaeology, 1993, 1994, 1996a, 1996b, 1997; Lang and Keen, 2005; Stringer, 2006; McNabb, 2007).

The palaeo-climatic context for Britain's early Middle Pleistocene archaeology is a series of four interglacial-glacial cycles (including late MIS 19 and early MIS 12) identified through the MIS and ice core records (e.g. Bassinot et al., 1994; Loulergue et al., 2008; Table 1). Modelled surface air temperatures (Bintanja et al., 2005, Fig. 2) suggest severe cold in MIS 16 comparable to MIS 12 (with the most extreme of the Northern Hemisphere surface air temperatures for the last 700kyr modelled at $17^{\circ} \mathrm{C}$ below present). By contrast the model's temperature estimates for the interglacial stages fall below the levels for MIS 11 and 5e. Identification of all of these stages in the British terrestrial record has however been highly problematic (Mitchell et al., 1973; Bowen et al., 1999; see Preece, 2001, Stuart and Lister, 2001, and Rose, 2009 for recent reviews). As part of the resolution of these issues, critical geochronological debates are ongoing with regards to the lowland glaciations of East Anglia (e.g. Lee et al., 2004a, 2006a; Hamblin et al., 2005; Rose, 2009; Preece and Parfitt, 2008; Preece et al., 2009; Table 2). This paper therefore discusses the implications of both of the principal lowland glaciation models for the archaeological evidence, although tentatively favouring the 'biostratigraphic age' model of Preece et al. (2009; Section 2.1). In light of current geochronological uncertainties it is 
therefore also assumed that the archaeology of the British early Middle Pleistocene is primarily the product of Homo heidelbergensis (Roberts et al., 1994), although it is possible that the Pakefield material at least may be associated with one or more of the earlier hominin species identified in the Early Pleistocene and early Middle Pleistocene of southern Europe: Homo erectus (Ascenzi et al., 2000) and Homo antecessor (Bermúdez de Castro et al., 1997; Carbonell et al., 2008). The early Middle Pleistocene is used throughout to refer to the period MIS 19-12, and although local terminology has been avoided whenever possible, definitions are provided where necessary upon first usage.

\section{Occupation History}

The landscape of southern Britain between MIS 19-12 was dominated by three rivers (Figure 1): the Bytham (flowing eastwards from the West Midlands through East Anglia and out into the region of the present day North Sea: Rose, 1987, 1994, 2009; Lewis, 1998); the Thames (flowing from the Cotswolds in its present valley until Reading, before flowing north-eastwards through the Vale of St. Albans and eastern Essex and out into the North Sea region: Rose and Allen, 1977; Whiteman, 1992; Whiteman and Rose, 1992; Bridgland, 1994; Rose et al., 1999a), and the Solent River (flowing eastwards past the Isle of Wight before turning southwards into the area of the English Channel; Allen and Gibbard, 1993; Bridgland, 2001; Westaway et al., 2006). A fourth river, the Ancaster, has been argued to have flowed from the southern Pennines across an area north of the contemporary Norfolk coastline, although its high-level terraces have not been identified and its course was instead reconstructed on the basis of rockhead relief (Clayton, 2000; Rose, 2009). During this period the present-day low-lying area of eastern England (the Wash and the Fens; Figure 1) was characterised by greater elevations (it was subsequently excavated by the MIS 12 ice sheet), with a higher relief Chalk escarpment, that linked the Chilterns and the Yorkshire Wolds, lying further to the west than the contemporary East Anglian escarpment (Lewis, 1998; Clayton, 2000).

During the early Middle Pleistocene Britain was fully connected to the continental landmass between the area of the present day southern North Sea and below the Strait of Dover (Preece, 1995; Figure 1), with the breaching of the Strait not occurring until the later Middle Pleistocene (probably initially during MIS 12: Smith, 1985; Gibbard, 1995, 2007; Gupta et al., 2007). Other major north-western European rivers also drained into and through this landscape to the margins of the North Sea and English Channel respectively, including the Rhine, Somme, and Seine (Rose, 2009, Fig. 12).

The majority of the known early Middle Pleistocene archaeological sites in Britain were associated with the Bytham River landscape in the Midlands and East Anglia (mostly in the latter region; Figure 2), although artefacts also became incorporated into the deposits of the pre-diversion Thames system (Figure 3) and the Solent River system (Figure 4), the coastal plain in the area of West Sussex (Figure 4), and a small number of caves in the south-west of Britain (Figure 1). Chalk flint and river gravel flint resources were widely available in the middle and lower reaches of the Thames, the upper reaches of the Solent River and its northbank tributaries, and the West Sussex coastal plain (Whiteman, 1992; Allen and Gibbard, 1993; Bridgland, 1994; Roberts and Parfitt, 1999). Chalk flint was also available in the landscapes of the lower reaches of the Bytham (within and eastwards of the southern sweep of the river, along which the key sites of High Lodge and Warren Hill lie: Figures 1 and 2), while the river's deposits contained abundant quartz, and quartzite, combined with locally derived flint (Rose, 1994; Bridgland et al., 1995; Lewis, 1998). In other areas, such as the West Midlands (the upper reaches of the Bytham River) and the upper reaches of the Thames, quartz and quartzite were the predominant locally available resources for tool-making (Rose, 1987; Shotton et al., 1993; Bridgland, 1994; Stephens et al., 2008). The following sections provide short summaries of the key British sites and assemblages dating to the MIS 19-ealy MIS 12 period, organised by regions (East Anglia, the British Midlands, the pre-MIS 12 Thames Valley, the West Sussex Coastal Plain, the Solent River, and the South-West; Figures 1-4), and specific river systems, where appropriate.

\subsection{East Anglia}

East Anglia has been a key focus in recent explorations of Britain's pre-MIS 12 archaeology, with the re-investigations of High Lodge (Ashton et al., 1992a) and the new fieldwork at Pakefield (Parfitt et al., 2005; Parfitt, 2008) and Happisburgh (Ashton et al., 2008), combined with various studies of the Bytham terraces and the region's glacial deposits (Lewis, 1998; Lewis et al., 1999; Rose et al., 1999b, 2001; Lee et al., 2004a, 2006a; Hamblin et al., 2005; Read et al., 2007; Gibbard et al., 2008; Pawley et al., 2008; Rose, 2009; Preece et al., 2009; Gibbard et al., 2009; Westaway, 2009). Central to the resolution of the ages of much of East Anglia's early Middle Pleistocene archaeology has been 
the recent debates between two models addressing the region's glacial history and stratigraphy: the 'new glacial stratigraphy' model (Hamblin et al., 2000; Lee et al., 2004a, 2004b, 2006a, 2008a; Hamblin et al., 2005; Rose, 2009), and the 'biostratigraphic age' model (Preece, 2001; Stuart and Lister, 2001; Preece and Parfitt, 2008; Preece et al., 2009). The principal supporting evidence for the alternative models, which have major implications not only for the age of the Happisburgh 1 and Pakefield archaeology (Sections 2.1.1 and 2.1.2.1) but also for the artefact assemblages associated with Bytham River deposits inland from the coast (Section 2.1.2), is presented in Table 2 (see the above references and papers within Lewis et al., 2000 and Candy et al., 2008 for a full discussion of these issues).

The 'new glacial stratigraphy' model has re-classified various East Anglian glacial tills, previously thought to all be of MIS 12 age but formed by co-existing ice sheets of northern Britain and Scandinavian origin (Bowen et al., 1986). A series of distinct tills of different MIS ages have instead been proposed (Table 2) on the basis of sedimentary characteristics, till lithologies and inferred ice flow directions (Lee et al., 2004b; Hamblin et al., 2005; Rose, 2009), with a Scandinavian origin assigned only to selected deposits within the youngest (MIS 6) of the new glacial formations (but see the discussions in Hoare et al., 2006; Lee et al., 2006b regarding the presence or absence of Scandinavian erratics). The age of the MIS 12 glaciation is well established, on the basis of relationships with the River Thames' terrace aggradations and absolute OSL, ESR and U-Series dates on MIS 12 and 11 deposits (Bridgland, 1994; Rowe et al., 1999; Grün and Schwarcz, 2000; Pawley et al., 2008). However the age of the underlying glacial deposits (principally the Corton Till and Happisburgh Till of the proposed Happisburgh glaciation; Table 2) is much more controversial. Hamblin et al. (2005) suggested that these deposits dated to a separate, earlier glaciation on the basis of intervening unconformities, and differences in the degree of weathering, while it has also been argued that the Corton Till was separated from the overlying Lowestoft Till by shallow marine deposits (i.e. non-glacial conditions) at Chapel Hill (Read et al., 2007) and by temperate climate soils at other sites (Rose, 2009). However the critical evidence for the 'new glacial stratigraphy' has been the proposal that the $3^{\text {rd }}$ (Timworth), $2^{\text {nd }}$ (Warren Hill) and $1^{\text {st }}$ (Castle Bytham) terrace aggradations of the Bytham River can be assigned, respectively, to MIS 16, 14 and 12. This is according to a c. $100 \mathrm{kyr}$ cycle of terrace formation and an early MIS 12 age for the Castle Bytham Terrace aggradation (the latter is indicated by a continuous sequence of sedimentation demonstrating a change from fluvial conditions through to a lake impounded by the MIS 12 ice sheet). This has led to the proposal of an MIS 16 age for the Happisburgh glaciation, on the basis of its characteristic heavy minerals, till clasts and erratics occurring in the Timworth Terrace at Leet Hill (Figure 2), which must therefore post-date the Happisburgh glaciation (Rose et al., 1999b; Lee et al., 2004a; Rose, 2009).

The 'biostratigraphic age' model proposes only an MIS 12 glaciation for the early Middle Pleistocene in East Anglia, primarily on the basis of two lines of evidence. Firstly the AAR dating at Sidestrand, which indicates an MIS 11 or 9 age for temperate sediments capping the glacial sequence (encompassing the MIS 16, 12 and 10 glaciations of Hamblin et al., 2005), and an MIS 13, or late 15, age for the temperate sediments underlying the Happisburgh Till at the base of the glacial sequence (Preece et al., 2009). Secondly the biostratigraphy and in particular the presence of Arvicola, thought to post-date MIS 16, in temperate sediments underlying the Happisburgh Till at Sidestrand, Happisburgh 1 and Ostend (Preece et al., 2009).

Both models have received criticism: Lee et al. (2004a, 2006a) raise doubts regarding the 'biostratigraphic age' model, on the basis of the possibility of a sub-eccentricity-forced signal in the biostratigraphic record (i.e. the connection between full MIS stages and the first and last appearances of biostratigraphic marker species may be uncertain), and the possibility of progressive evolution and evolutionary diachronism within species across wider regions (Western Russia to Britain), drawing into question the value of the Mimomys > Arvicola transition as a biostratigraphic marker. Defending the 'biostratigraphic age' model, Preece and Parfitt (2008) and Parfitt et al. (2009) have highlighted the difficulties of reconciling the biostratigraphy with the 'new glacial stratigraphy', in particular the problem of trying to fit three early Middle Pleistocene temperate stages containing Mimomys into a narrow time interval between later MIS 19 and MIS 17 (required by an MIS 16 age for the Happisburgh Till and the presence of Arvicola beneath that till). They have also defended the multiproxy (with mutually independent checks as opposed to circular reasoning) basis of the 'biostratigraphic age' model. Concerning the Bytham terraces, Preece and Parfitt (2008) have emphasised the impacts of glacial disruption and crustal movement upon terrace formation, with reference to MIS 12 multiple terrace formation in the Thames (Maddy and Bridgland, 2000) and the 
'double' terraces per cycle of the Solent River (Bridgland, 2001; Westaway et al., 2006). This led Preece and Parfitt (2008) to question the assumptions of the 100kyr terrace cycle as applied to the Bytham and suggest that all three of the Bytham Terraces may represent a complex MIS 12 stage. The Bytham terrace correlations of Lee et al. (2004a, Fig. 7) also extend over considerable distances (c. $110 \mathrm{~km}$ from Shouldham to Leet Hill), in contrast to the earlier correlations of Lewis (1998, Figs. 7.2 and 7.3) over a much smaller area between Mildenhall and Bury St. Edmunds (c. 15-20km). These long-distance correlations, and therefore the age of the critical Leet Hill deposits, are a further point of concern in a region with significant and differential tectonic subsidence and uplift (Rose, 2009;

Westaway, 2009) and highly fragmented Bytham river deposits (Rose, 1987). Westaway's (2009) remapping and proposal of three Bytham (Ingham) River terraces, resulting in MIS 13 or early MIS 12 ages for the sites of Warren Hill, High Lodge, Lakenheath, and Feltwell, is also in opposition to the 'new glacial stratigraphy' model, although Rose (2009) has criticised Westaway's interpretation for ignoring palaeosol surfaces and mixing the Bytham terraces with glaciofluvial and postglacial aggradations/terraces of the river Waveney.

\subsubsection{Happisburgh 1}

The site of Happisburgh (Figures 1 and 2) lies on the north-east Norfolk coast, with glaciogenic sediments exposed in the coastal cliffs and pre-glacial sediments occurring beneath the modern beach. The archaeology at Happisburgh 1 occurs within organic muds, exposed only through the removal of overlying beach materials during low tides, deposited within a floodplain environment. The muds form part of the Cromer Forest-bed Formation (primarily organic detritus muds and sands deposited within the channels and on the floodplains of the rivers draining central and eastern England prior to and during the early Middle Pleistocene; Rose et al., 2001, Fig. 5; Parfitt et al., 2005), and are overlain by the Happisburgh Till (Ashton et al., 2008; Lee et al., 2008b). Lying between the inferred routes of the Bytham and Ancaster Rivers (Rose, 2009, Fig. 8 and 11), it is currently uncertain which river deposited the Happisburgh 1 floodplain sediments, although Rose's reconstruction of the early Middle Pleistocene palaeogeography (2009, Fig. 8c) favours the Ancaster. The artefact assemblage includes lithics collected both through formal excavation in 2004 and through the periodic monitoring of the organic muds when exposed by low tides, which followed on from the initial biface find in 2000 (Ashton et al., 2008).

The age of the Happisburgh 1 organic muds has been much debated, varying between an MIS 17 or earlier age, based on the 'new glacial stratigraphy' re-analysis of the East Anglian glacial sequence and an MIS 16 assignment for the Happisburgh Till (Lee et al., 2004a; Hamblin et al., 2005), and an MIS 13 (or possibly 15) age, based on the vertebrate, coleopteran, and AAR evidence (Preece, 2001; Stuart and Lister, 2001; Coope, 2006; Preece et al., 2009). An MIS 12 age for the Happisburgh Till and an MIS 13 (or late 15) age for the Happisburgh 1 organic muds is tentatively favoured here, primarily on the grounds of the AAR data (Preece et al., 2009), but it is acknowledged that there are a number of outstanding issues of debate (e.g. the robusticity of the biostratigraphy and the number, and mode of formation, of the Bytham terraces) and that therefore the age of much of the East Anglian archaeology from the early Middle Pleistocene is yet to be conclusively resolved (Tables 1 and 2).

The excavated Happisburgh 1 assemblage is made up of 38 flakes, four retouched pieces, and two possible cores (small chunks of frost-shattered flint with single flake removals), with a similar range of artefacts in the monitoring sample (Ashton et al., 2008). There is just a single possible soft-hammer flake (potentially suggestive of biface technology), with the remainder of the flakes removed by hardhammers, probably from simple cores (Ashton et al., 2008). The four flake tools feature either notches or denticulated retouch (Ashton et al., 2008). The dispersal of the material throughout the muds suggests an absence of discrete in situ knapping scatters, although the artefacts' fresh condition does suggest that they are in primary context (Ashton et al., 2008). The occurrence of knapping activity close to the site is suggested by the probable knapping waste, but while occasional small nodules are found in the organic mud, some of the flakes appear to come from larger nodules of unknown source (Ashton et al., 2008).

\subsubsection{The Archaeology of the Bytham River}

\subsubsection{Pakefield}

The Pakefield site consists of recently exposed coastal sections of the Cromer Forest-bed Formation and associated deposits between Pakefield and Kessingland (Figure 2 and Table 3; Parfitt et al., 
2005). The archaeology occurs across a range of contexts within an interglacial infill of a Bytham River channel, which was incised into Early Pleistocene marine sediments and which is overlain by a sequence of marine sands and glaciofluvial sediments of disputed age, and MIS 12 till (Parfitt et al., 2005). The oldest artefact was recovered from the upper levels of the estuarine silts, which are either part of the Cromer Forest-bed Formation (Parfitt et al., 2005, Fig. 3) or part of shallow marine deposits (the Wroxham Crag Formation; after Lee et al., 2006a). All of the remainder were found in the Cromer Forest-bed Formation: overbank sediments also known as the 'Rootlet bed' ( 2 artefacts); a sandy lag gravel, also referred to as the 'Unio-bed', at the base of the laminated silts which fill the channel cut into the overbank sediments (28 artefacts); and laminated silts at the edge of the channel (1 artefact; Parfitt et al., 2005). Although all of the sediments overlying the channel infill were originally interpreted as MIS 12 glaciofluvial deposits, Lee et al. (2006a) proposed a more complex sequence, including shallow marine sands, Bytham River sands and gravels, glaciofluvial sands and gravels, and further marine sands, prior to the subglacial till of MIS 12.

The significance of Lee et al.'s (2006a) re-interpretation of the Pakefield sequence primarily relates to the wider debates regarding the early Middle Pleistocene's lowland glaciation history in East Anglia. Lee et al. have identified high sea level events both underlying Happisburgh glaciation (MIS 16 fluvial and glaciofluvial) deposits and, critically, occurring between the Happisburgh glaciation deposits and Lowestoft (MIS 12) Till. Combined with Lee et al.'s (2004a) Bytham River terrace model, a temperate interglacial stage age for the intervening high sea level event (either MIS 13 or 15) supports an MIS 16 Happisburgh glaciation. However Gibbard et al. (2008) have strongly criticised this interpretation of the upper part of the Pakefield sequence, and argue that all of the sediments above the Cromer Forest-bed Formation represent glaciofluvial deposition of MIS 12 age, with no evidence for the marine and non-glacial sediments of Lee et al. (2006a), and therefore no evidence for a pre-MIS 12 East Anglian glaciation (but see also the response of Lee et al., 2008a; Table 3). The post-Cromer Forest-bed Formation portion of the Pakefield sequence therefore has implications for the age of the Happisburgh 1 archaeology as well as that of Pakefield itself.

The Cromer Forest-bed Formation deposits at Pakefield are suggested to date to an early interglacial stage in the early Middle Pleistocene, either MIS 17 or MIS 19 (see Parfitt et al., 2005; Lee et al., 2006a for further details; cf. Westaway, 2009). This age assignment is based on a number of lines of evidence, including: (i) the presence of the vole species $M$. aff. Pusillus (its last appearance in European Russia pre-dates MIS 16); (ii) the normal polarity of the laminated silts (consistent with the early part of the Brunhes Chron); (iii) AAR data which suggests that the opercula samples from Pakefield are at least as old as those from the nearby West Runton Freshwater Bed (Figure 2), widely interpreted as dating to a temperate stage early within the early Middle Pleistocene (Preece, 2001; Stuart and Lister, 2001); and (iv) the sedimentological evidence, interpreted by Lee et al., 2006a (but cf. Gibbard et al., 2008) as separating the Pakefield Cromer Forest-bed Formation deposits from the MIS 12 till by two separate high sea stands and two cold episodes tied into the MIS record. An MIS 16 Happisburgh Till age therefore suggests an MIS 19 age for the Pakefield Cromer Forest-bed Formation deposits, due to the intervening high sea-level (MIS 17?) and cold (MIS 18?) events (Parfitt et al., 2005; Table 3).

The general environment consists of the lower reaches of a large, meandering river, with a mixture of active channels and cut-off pools on the floodplain (Coope, 2006; Lee et al., 2006a). The archaeology initially consisted of 31 flakes (including one crudely retouched piece) and a single core, indicative of a simple core and flake technology, although the small sample size should promote caution in such an interpretation (Parfitt et al., 2005). Two further artefacts, a core and hard hammer flake were subsequently recovered in 2006, also from the 'Unio bed' (Parfitt, 2008). The waterworn cortex and unworked surfaces are suggestive of the use of local fluvial gravels, probably collected from either the sandy lag gravels at the base of the channel or from earlier Bytham terrace deposits located beyond the floodplain, while the presence of micro-débitage indicates that knapping occurred on site (Parfitt et al., 2005; Parfitt, 2008). Although the majority of the artefacts originate from the 'Unio-bed', the recovery of occasional pieces from other contexts (the overbank sediments, channel edge silts, and the underlying estuarine deposits, in particular the latter) would appear to suggest that the archaeology does not represent a single phase of occupation (Parfitt et al., 2005).

\subsubsection{Warren Hill}

The rich biface site at Warren Hill (Figure 2) was once thought to be associated with glaciofluvial outwash deposits (Solomon, 1933), and a similar re-interpretation has been recently proposed by 
Gibbard et al. (2009), both for Warren Hill and other Bytham River sites. However examination of clast lithological data in the 1990s led to a rejection of Solomon's (1933) original interpretation, with the evidence favouring both a pre-MIS 12 glaciation age (the absence of Rhaxella chert) and a fluvial origin (indicated for example by open framework gravel on steeply dipping foresets; Bridgland et al., 1995). These fluvial deposits were assigned to the Bytham river on the grounds of clast lithology and palaeoflow direction (Wymer et al., 1991; Bridgland et al., 1995), although the altitudinal position of the Warren Hill sequence makes correlation with other Bytham river deposits difficult (Lewis, 1998).

The artefacts, including over 2,000 bifaces and several hundred flakes (Roe, 1968; Wymer, 1985), are primarily characterised by a division between well made (thin and symmetrical) and little or unrolled ovates and cordates, and thicker, 'cruder' implements in a heavily rolled and battered condition (Wymer et al., 1991), although other divisions of the material have also been presented (Solomon, 1933; Roe, 1981; Bridgland et al., 1995). While thinking regarding the significance of typological variation has shifted over recent decades (e.g. Roe, 1981; White, 1998), variation in artefact condition does suggest the possibility of two assemblages, as does the frequent use of the local East Anglian black flint in the second of the two 'groups' (Roe, 1981; Wymer et al., 1991; Bridgland et al., 1995). Also of note are the apparent similarities between some of the finer Warren Hill scrapers and those from High Lodge (Wymer et al., 1991; Section 2.1.2.3).

While the exact origins of the entire assemblage are rather unclear, the considerable edge damage (even on those bifaces described as 'unrolled' on the basis of their flake scar abrasion; Wymer et al., 1991; Bridgland et al., 1995) strongly suggests that the artefacts all came from the higher energy sands and gravels described by Wymer et al. (1991) and Bridgland et al. (1995), as opposed to the underlying sands and silts (the small number of artefacts located during the early 1990s fieldwork were also limited to the higher energy sediments: Bridgland et al., 1995, Fig. 2). The physical condition of the artefacts also raises the possibility that at least a component of the assemblage was derived from older deposits. Following the position that the Warren Hill deposits do relate to the Bytham River (after Bridgland et al., 1995; but cf. Gibbard et al., 2009, which with the exception of Pakefield re-designates the key East Anglian Bytham River artefact assemblages to post-MIS 12 and beyond the scope of this paper), an early MIS 12 or MIS 13 age is provisionally favoured here. These ages have been proposed on various grounds by Wymer et al. (1991), Bridgland et al. (1995), Lewis (1998), Preece and Parfitt (2008; who suggested that the Timworth, Warren Hill and Castle Bytham terraces may all represent a complex MIS 12 stage), and Westaway (2009; but cf. Rose, 2009). However the Lee et al. (2004a) Bytham terrace model is also acknowledged, as is the outstanding problem for those favouring the 'biostratigraphic age' model of the need to 'fit' multiple Bytham terrace incision and aggradation events into MIS 13/early MIS 12 (Table 2). Lee et al.'s (2004a) MIS 14 age for the Warren Hill Terrace aggradation would clearly increase the age of the Warren Hill artefacts, probably into MIS 15 in light of the evidence for biface re-working (Table 4).

\subsubsection{High Lodge}

The High Lodge site (Figure 2 and Table 3) has a long history of research, reflecting the complex taphonomic processes which modified the site sediments, and the tensions between geological interpretations and traditional views of the lithic industries (see Ashton, 1992a for full details). The recent work of Ashton et al. (1992a) has demonstrated that the oldest sediments at the site are the pre-MIS 12 fluvial floodplain clayey-silts, which reflect low energy environments and are the original source of the site's core and flake material. The clayey-silts' minimum age is also indicated by the recovery of a Stephanorhinus etruscus tooth, as this species has only been recovered from Early and early Middle Pleistocene sites in Britain, and appears to be replaced by $S$. kirchbergensis and $S$. hemitoechus in post-MIS 12 contexts (Stuart, 1992). The clayey-silts were subsequently transported and deformed by an MIS 12 ice-sheet, resulting in their overlying the younger glacial deposits. During late MIS 12 the clayey-silts were then buried by glaciofluvial sands and gravels, the source of the High Lodge bifaces. The presence of these artefacts in the MIS 12 glaciofluvial deposits again suggests a probable pre-MIS 12 age for their manufacture and discard, on the grounds of likely climatic tolerances (Ashton et al., 1992b). Unfortunately the transported nature of the clayey-silts made it impossible for Lewis (1998) to fit the sediments onto the reconstructed gradients for the Bytham River (but cf. Lee et al., 2004).

The artefact assemblages from High Lodge fall into three groups: those collected between 1870 and the early 1920s (characterised by limited contextual and provenance information); those from the 1962-68 British Museum excavations; and those from the 1988 British Museum excavations (Ashton, 
1992b). The artefacts from the clayey-silt beds excavated in the 1960s are characterised by an unusual combination of discrete in situ scatters alongside a high proportion of missing pieces, which Ashton (1992b) assigns to the movement and shearing of the clayey-silts by ice action. All of the raw material used was local East Anglian flint, dominated by unweathered Chalk flint with a smaller proportion derived from local gravel sources (Ashton, 1992b). While the older collections were biased towards scrapers, Ashton's (1992b) re-analysis of the flake tools suggested three groups: (i) flaked flakes and Clactonian notches (Figures 5a and b), (ii) denticulates (Figure 5c), and (iii) scrapers, including both the 'classic High Lodge' forms (Figure 5e) and those with minimal edge modification (Figure 5d). While no direct evidence of use was forthcoming, it is likely that in some cases at least there was little functional difference between the denticulates and the notches (Ashton, 1992b). While this material has been interpreted in detail by Ashton (1992b) and Ashton and McNabb (1992), it is worth re-emphasising that the well made, invasively retouched High Lodge scrapers, the importance of which was frequently over-emphasised in the early $20^{\text {th }}$ century, are not unique within the British Lower Palaeolithic (Ashton and McNabb, 1992). Turning from flake tools to the sources of those flakes, although previous authors have described the High Lodge cores as 'shapeless' or 'crude', Ashton (1992b) has argued for evidence of patterned flake removal, characterised by the use of four principal techniques (single removal; single platform; alternate platform; alternating platform) in a series of staged progressions. The carefully made ovate and limande bifaces from the contorted sands above the clayey-silts show frequent evidence of tranchet finishing or re-sharpening, with soft hammer flaking in all cases and frequent working of the biface butts (although some remnant cortex was common). The tendency of the bifaces to be only slightly abraded suggests derivation from a nearby location (Ashton and McNabb, 1992).

\subsubsection{Other Bytham River Sites}

Other important locations along the Bytham River include Feltwell (Shrub Hill and Frimstone), Hockwold-cum-Wilton, Brandon Fields (Gravel Hill), Icklingham (Rampart Field), Eriswell, and Lakenheath (Maidscross Hill) (Roe, 1981; Wymer, 1985, 1999, 2001; Bridgland et al., 1995; Table 1 and Figure 2). There are also several hundred further artefacts, predominantly bifaces, provenanced generally from the areas of Brandon, Lakenheath, Mildenhall, and Icklingham, which therefore may be, but cannot be securely demonstrated as, pre-MIS 12 in age (Wymer, 1985). Artefact evidence of potentially pre-MIS 16 age (after Lee et al., 2004, Fig. 7) has also been claimed from Hengrave (Rose and Wymer, 1994). However the English Rivers Palaeolithic Survey (Wessex Archaeology, 1996b) expressed doubts regarding the authenticity of the single flake from the site, and also questioned the status of three possible flakes from Timworth (see also Lewis, 1998). As discussed in Sections 2.1.1 and 2.1.2.2, a series of different terrace models have been proposed for the Bytham River (Lewis, 1998; Lee et al., 2004a; Preece and Parfitt, 2008; Westaway, 2009), which have potentially significant consequences for the chronology of the sites and artefacts (Table 4). Unfortunately the fragmentary nature of the deposits makes the assignment of many of the key sites to specific terraces difficult. Nonetheless the terrace ages of Lee et al. (2004a), if correct, would suggest an enhanced pre-MIS 13 presence in the East Anglian region (probably reaching back to at least MIS 15) and as such would be important for assessing the nature and timing of the earliest human occupation of northern Europe.

While flint was widely available and utilised in this landscape it is notable that Hardaker and MacRae (2000) report, amongst a larger assemblage of well-made flint artefacts (Wymer, 2001 lists at least 50 bifaces), 15 quartzite pieces (simple flakes, chopper-cores and split pebbles; Figure 6) from Frimstone. This is suggestive of at least the occasional use of immediately available raw materials, albeit with generally poorer flaking properties than flint, and small numbers of quartzite bifaces and hammerstones have also been found at Warren Hill, $10 \mathrm{~km}$ to the south (Wymer et al., 1991). Bifaces tend to dominate the Bytham River terrace sites generally, with over 2000 at Warren Hill and over 200 and 100 at Shrub Hill and Brandon Fields respectively, although in much smaller numbers at Lakenheath (Maidscross Hill) and Icklingham (Rampart Field; Wymer, 1985, 1999). However this biface-dominance may at least in part reflect histories of collection and the effects of fluvial reworking. The condition of the artefacts also varies, with the majority of the Shrub Hill bifaces described as 'rolled' or 'very rolled', while the material at Hockwold-cum-Wilton was 'far less rolled' (Wymer, 1985).

\subsubsection{Glacial and Glaciofluvial Sites}

Scattered artefact finds, predominantly bifaces, are also associated with glacial and glaciofluvial deposits in the East Anglian region. These include the deposits at North Cove, where the Corton Till has been suggested to be either intra-MIS 12 in age (after Preece and Parfitt, 2008) or MIS 16 in age 
(Lee et al., 2004a), and the MIS 12 till deposits at Stibbard (Wymer, 1985). There are also various sites linked to the glacial outwash gravels to the south of the Cromer Ridge (Wymer, 1999), although Hamblin et al. (2005) argue that the Cromer Ridge and its associated deposits are MIS 6 in age. The pre-MIS 12 potential of such artefacts are therefore dependent on the current interpretations of the East Anglian tills and outwash deposits, although it should also be noted that they are dwarfed in scale by the thousands of artefacts associated with the Bytham River sites (Section 2.1.2).

However Gibbard et al. (2009) have recently re-interpreted a series of East Anglian deposits as glaciofluvial delta-fans and related sediments: these include the important archaeological sites of Warren Hill, Maidscross Hill (Lakenheath), Hockwold-cum-Wilton, Brandon Fields, and Frimstone (Figure 2). The provisional interpretation of the artefacts from these sites as being re-worked from local sources by glacial action and re-deposited within delta-fan sediments of probably MIS 6 age clearly has very significant implications for the early Middle Pleistocene archaeological record in East Anglia.

\subsection{The British Midlands}

\subsubsection{The Bytham River}

Artefacts have been recovered from the deposits of the Bytham River (Rose, 1987, 1994) within the West Midlands (Figures 1 and 2) for a number of years, primarily from the gravel and sand pits around the villages of Baginton, Brandon and Bubbenhall (e.g. Shotton, 1930; Shotton et al., 1993; see Lang and Keen, 2005 for a fuller list of references). The Bytham River is represented at these sites by sands and gravels deposited by a braided river (the Baginton Formation; Table 3), underlying till and other cold climate deposits of MIS 12 age (Shotton et al., 1993). At Waverley Wood Quarry, the Baginton Formation sands and gravels are underlain by a complex of fluvial channels (the Waverley Wood Member), which have been interpreted as interglacial channel fills of later early Middle Pleistocene age, probably MIS 13 or late MIS 15 (Shotton et al., 1993; Lang and Keen, 2005; Keen et al., 2006; Preece et al., 2009).

Until recently the vast majority of the artefacts and large mammal fauna had not been found in situ, raising doubts as to their exact provenance and age (Keen et al., 2006), although Shotton et al. (1993) argued that the sharp condition of some of the bifaces supported a probable origin in the finegrained channels at the base of the sequence. Between 2004-6 however further Palaeoloxodon antiquus bones and teeth and an in situ andesite biface were recovered from another fluvial channel (the Waverley Wood Member) at Wood Farm Quarry (to the immediate north-east of the Waverley Wood Quarry), alongside further andesite, flint, and mainly quartzite artefacts (Keen et al., 2006). The range of artefact conditions suggests a mixed assemblage, with their concentration in a relatively small part of the pit being the product of fluvial activity, but it was concluded that the freshest pieces were only derived from local sources (Keen et al., 2006). A further andesite biface has also been recovered at Rearsby, although it is currently unclear how or if it relates to the nearby Bytham river deposits, including channel fills, at Brooksby (Coope, 2006; Stephens et al., 2008; Figure 2).

North-east of Coventry (Figure 2) a notable surface collection of bifaces and other artefacts has been recovered by R. Waite, centring around Bramcote, Burton Hastings, and Wolvey (Saville, 1988; Stephens et al., 2006). Although such surface material would normally be highly problematic, Wymer (1999) has noted that the artefacts' condition and distribution suggest a derivation from an outwash gravel (the Dunsmore Gravel) of an MIS 12 (the Oadby Till) ice sheet. Rose (2009) has proposed an MIS 10 age for the Oadby Glaciation, based on the relationship of the Oadby Till to the fluvial terraces and aggradations of the Upper Thames (Sumbler, 1995, 2001), and the number of post-Oadby Till aggradations in the Midlands catchments (Keen, 1999). However this chronology has not been supported by OSL dating of the Middle Pleistocene glacial sediments in north Norfolk (Pawley et al., 2008), which found a lack of evidence for an MIS 10 glaciation in this area (glacial deposits of MIS 10 would have been expected given that the Oadby Till was deposited by ice from the north-east, either from central Lincolnshire or through the Wash). If artefacts were re-worked from older, pre-MIS 12, surfaces by the Dunsmore Gravel, then at least some of the Waite Collection material may therefore be early Middle Pleistocene in age. There are a small number of other isolated finds from the British Midlands (Figure 1), including two bifaces, one of quartzite (Lang and Keen, 2005), from glacial deposits of probable MIS 12 age in the Birmingham area (Powell et al., 2000), which are likely to have been re-worked from earlier deposits or landsurfaces (Lang and Keen, 2005). 


\subsubsection{The Trent Valley}

No evidence has yet been found for a pre-MIS 12 drainage in the Trent Valley, which may reflect the inferred existence of the Ancaster river in the early Middle Pleistocene (Figure 1), although the large palaeovalleys filled with pre-Devensian glacial deposits beneath the Middle Trent have been argued to offer the greatest potential for future discoveries (Howard et al., 2007). However two cores and a flake, all of quartzite, have recently been discovered in a pit at East Leake (Figure 2), where they were associated with terrace/outwash gravel of possible MIS 12 age. Their heavily rolled condition further indicates that they may pre-date MIS 12 (White et al., 2008).

\subsection{The Thames and its Tributaries}

While the MIS 12 disruption of the Thames' drainage (Gibbard, 1985, 1994; Bridgland, 1994) significantly transformed the river, terrace deposits of early Middle Pleistocene age survive both in the Upper and Middle Thames regions (albeit relatively limited in extent) and in the pre-diversion route through the Vale of St. Albans into eastern Essex. There are extensive spreads of the terraces of the Colchester Formation (Kesgrave Sands and Gravels; MIS 21-12: Rose et al., 1999; Figure 3), particularly in eastern Essex, in light of which the paucity of archaeology identified from those deposits is especially surprising.

There are three single biface findspots associated with the pre-ancestral Thames' Kesgrave Sands and Gravels around Braintree (Figure 3), although Wymer (1999) expresses caution with regards to this provenance (the specific terrace is not indicated by Wymer, but Whiteman, 1992, Fig. 6 suggests that Kesgrave Sands and Gravels around Braintree would form part of the Early Pleistocene Sudbury Formation). Evidence from the younger Colchester Formation includes: (i) the two possible flakes from the Medway's temperate terrace deposits at Wivenhoe (Bridgland, 1994; the Wivenhoe Terrace is suggested to be MIS 14 in age by Maddy et al., 2001); (ii) the Ardleigh biface which may originate from the earlier Ardleigh Gravel (MIS 18; Maddy et al., 2001); and (iii) various small-scale findspots associated with glacial sands and gravels (at Colchester and Maldon; Figure 3; but cf. Bridgland, 1994) and the Cook's Green Gravel (suggested to be early MIS 12 by Bridgland, 1994, Table 5.3 and 5.6; Wymer, 1999; although it is also correlated by Bridgland, 1994 with the Wivenhoe Lower Gravel subsequently dated by Maddy et al., 2001 to MIS 14). These few artefacts are therefore the only possible examples of a pre-MIS 12 presence associated with the pre-diversion Thames and Medway in and around the area of the Tendring Plateau (Figure 3 and Tables 1 and 3 ).

There are small amounts of additional archaeological material of suggested early Middle Pleistocene age from the Middle Thames and its tributaries (Figure 3), although the evidence is sometimes uncertain. Wymer (1999) highlights: (i) artefacts from the gravel capping St. George's Hill at Weybridge (Wymer, 1999; argued by Gibbard, 1979 to date to early MIS 12), and the highest of the artefact-bearing River Wey gravels at Farnham (Terrace A) which may also be of MIS 12, and possibly pre-MIS 12, age (Gibbard, 1982); (ii) the bifaces from the Wallingford Fan Gravels, which grade into gravels of the early MIS 12 Upper Winter Hill Terrace of the Thames (Bridgland, 1994), and which would therefore indicate activity on the slopes or crest of the Chiltern's Chalk escarpment during early MIS 12 or earlier (Wymer, 1999); (iii) bifaces from the Gerrards Cross Gravel to the west of Reading (considered by Gibbard (1985) to precede the Winter Hill Gravels and be of early MIS 12 age, by Rose et al. (1999) to date to the late Early Pleistocene, and by Maddy et al. (2001) to date to MIS 22 and the Early Pleistocene, although the provenance of the artefacts is very uncertain: Wymer, 1999); and (iv) artefacts from the Kennet's (Figure 3) Silchester Stage gravels at locations between Reading and upstream of Newbury, although while Arkell (1947) correlated these deposits with the Winter Hill Gravels and therefore early MIS 12, both Bridgland (1994) and Gibbard (1985) associated them with the late MIS 12 Black Park Gravel (and therefore beyond this paper's coverage).

\subsection{The West Sussex Coastal Plain}

\subsubsection{Boxgrove}

Associated with the Westbourne-Arundel (previously referred to as the Goodwood-Slindon) Raised Beach of the Upper Coastal Plain Group (Pope et al., 2009), the late MIS 13/early MIS 12 site of Boxgrove (Figures 1 and 4 ) is situated in an evolving and climatically deteriorating landscape, broadly shifting from the open coastline of the Slindon Sands, through the lagoonal environment of the Slindon Silts, to the soil horizon and grassy plain which succeeded the sea's regression. The palaeosol and its overlying alder/fen carr organic deposit were progressively buried by silts (brickearth), fan gravels and gelifluctate (head gravels), reflecting the onset of colder conditions 
(Roberts and Parfitt, 1999). The significance of these deposits (Table 3) lies not only in the richness of the Boxgrove archaeology, but also in the presence of all of the principal sedimentary units along a $26 \mathrm{~km}$ stretch of the raised beach (Pope et al., 2009; Roberts and Pope, in press).

The Boxgrove site's rich archaeology is principally associated with the Slindon Silts and the palaeosol landsurface, but also occurs, both in situ and as residual artefacts, in the Slindon Sands and the fan and head gravels of the Eartham Formation's members (Table 3). It is particularly notable that the artefacts in the latter deposits were both derived, probably from earlier interglacial surfaces, and deposited directly by hominins during the colder climate conditions of the MIS 13/12 transition (Roberts and Parfitt, 1999). The Slindon Silts represent intertidal mudflats, deposited within a protected lagoon rather than on an open shore-face (Roberts and Parfitt, 1999). Within the silts a major landsurface developed briefly, upto $100 \mathrm{~m}$ in front of the Chalk cliff line cut at the back of the raised beach, as a result of the exposure of a silt surface out of the tidal reach. In situ archaeology and single activity events are notably associated with this landsurface and the low energy, inter-tidal regime (e.g. at the GTP 17 horse butchery site, and the Q1/A excavation area), although other debris was also dropped onto the silts at low tide. The subsequent soil and land surface development, open for an interval between 20 and 100 years, was characterised by a large gassy plain (Roberts and Parfitt, 1999). The duration of the landsurface has also resulted in an archaeological signature which, while in situ, is characterised by over-printing (Pope et al., 2009).

The Boxgrove archaeology is dominated by bifaces, over 500 in number and characteristically (although by no means exclusively) featuring slight asymmetry of shape and tranchet sharpening flakes at the tip (Roberts and Parfitt, 1999; Figure 7). Unlike the bifaces, which occur throughout the Boxgrove archaeology, flake tools are more localised, occurring primarily in the vicinity of the Q1/B waterhole site (Pope and Roberts, 2005). Organic technology is directly evident in the giant deer (Megaloceros dawkinsi) and red deer antler soft hammers (Pope and Roberts, 2005; Pope, 2003), and indirectly from the projectile wound explanation for the horse scapula puncture mark (Roberts and Parfitt, 1999, Fig. 289). Single sites (e.g. GTP 17) provide evidence both for the processing of individual carcasses (Roberts and Parfitt, 1999), and for related aspects of hominin behaviour such as flaking strategies (refitting scatters), raw material acquisition and transport, and possible co-operation (Roberts and Parfitt, 1999), while re-visited localities such as the waterhole site indicate longer-term patterns in land use (Pope and Roberts, 2005). The site is also rich in faunal remains, although such material was rarely recovered from the decalcified deposits (Roberts and Parfitt, 1999).

\subsubsection{Beyond Boxgrove}

Further archaeology from the 'Boxgrove' palaeolandscape has recently been identified at the Valdoe Quarry site (Pope et al., 2009; Figure 4). Investigations revealed a sedimentary sequence almost wholly comparable with that identified at Boxgrove and through the Raised Beach Mapping Project (Roberts and Pope, in press), including the inter-tidal silts and the palaeosol. The majority of the Valdoe artefacts, consisting of diagnostic débitage rather than formal tools or cores, were recovered from the palaeosol, with taphonomic investigations indicating preservation conditions for the palaeosol archaeology that were directly comparable with those at Boxgrove (Pope et al., 2009). The palaeosol artefacts were biased towards biface thinning and the later stages of biface manufacture, with little representation of the early stages of either biface manufacture or core reduction (Pope et al., 2009).

Additional artefact-bearing locations from the Westbourne-Arundel Raised Beach landscape include Slindon (Woodcock, 1981; Pope, 2001), sites in and around East Lavant village (Woodcock, 1981; Pope et al., 2009), and at a number of other pits (Woodcock, 1981; Roberts and Parfitt, 1999; Wymer, 1999; Figure 4). The integration of this material has been a key focus of the recent Raised Beach Mapping Project, work which has been critical in demonstrating the extents of the 'Boxgrove' landscape and assessing the possible contemporaneity of archaeological materials identified at different locations along the Raised Beach (Roberts and Pope, in press).

\subsection{The Solent River}

Beyond the limits of the MIS 12 glaciations there is probable evidence for pre-MIS 12 hominins in the artefacts, principally bifaces, associated with some of the highest and oldest terraces of the Solent River and its tributaries (Figure 4 and Table 1). These include the Sway, Tiptoe, and probably Setley Plain gravels of the Stour/Solent River around Bournemouth, the Setley Plain Gravel of the main Solent River channel in the western Solent, terrace 8 of the River Avon and terrace 6 of the River Test (Allen and Gibbard, 1993; Wessex Archaeology, 1993; Wymer, 1999; Westaway et al., 2006; Ashton 
and Hosfield, in press). Although many of these terraces only contain a handful of artefacts, richer archaeology is known from Test terrace 6 (c. 120 bifaces from the Ridge Gravel Pit, Romsey) and the Stour/Solent Setley Plain terrace gravels (c. 290 bifaces from the Corfe Mullen gravel pits). The key issue in the Solent is that the chronology of the Solent terraces remains much debated. Briant et al. (2006) propose MIS 7b-8 OSL ages for the Stanswood Bay Gravel in the western Solent, which lies 5 terraces below the Setley Plain Gravel. More recently Briant et al. (2009) and Briant and Schwenninger (2009) have suggested OSL ages of MIS 9-11 and 8-9 for the Old Milton Gravel (2 terraces below the Setley Plain Gravel) and the Tom's Down Gravel (3 terraces below the Setley Plain Gravel) respectively. These ages indirectly suggest an age around MIS 12/13 for the Setley Plain Gravel, based on the formation of two fluvial terraces per 100kyr cycle (Bridgland, 2001), while Bridgland et al.'s (2004, Table 3) correlations of the Solent terraces with the West Sussex raised beaches suggests an immediately pre-MIS 13 age for that gravel. The uplift-based model of Westaway et al. (2006, Fig. 3b) suggested ages of MIS 15b and 14 for the Sway and Tiptoe gravels of the Stour/Solent, and 13b for the Setley Plain Gravel in the western Solent, Avon terrace 8, and Test terrace 6. While Westaway et al. (2006, Fig. 3b) suggest an MIS 12 age for the Sleight Terrace (the source of the Corfe Mullen artefacts: McNabb and Hosfield, 2009), the physical condition of at least some of the artefacts (Ashton and Hosfield, in press) suggests re-working from earlier deposits (Roe, 2001 also argued for a pre-MIS 12 age on typological grounds). These various chronologies therefore appear to support a pre-MIS 12 presence in the Solent River system, although probably restricted to MIS 13. Claims have been made for bifaces from even higher terraces, especially those of the River Test (Wessex Archaeology, 1993), however their limited contextual data does not allow them to be accepted as unequivocal evidence for an earlier hominin presence (Ashton and Hosfield, in press).

\subsection{The South-Western Caves}

The only examples of cave archaeology in Britain during this period come, as indeed does much of Britain's Palaeolithic cave site evidence, from the south-west, most notably at the site of Kent's Cavern (Figure 1). The complex stratigraphy of William Pengelly's $19^{\text {th }}$ century excavations and the history of research (see Campbell and Sampson, 1971 for a summary of the early work; and Cook and Jacobi, 1998 for subsequent corrections to artefact provenance and context) have made interpretation of this site difficult. However it is clear that 15 bifaces (Figure 8) can be associated with the breccia (deposited by debris flows) in the lower part of the sequence, beneath crystalline stalagmite (flowstone) and Late Pleistocene 'cave earth' (Roe, 1981; Proctor et al., 2005; Cook and Jacobi, 1998). While a rich fauna has often been attributed to the breccia deposit, re-analysis by Cook and Jacobi (1998) indicated that the source of many of the specimens was uncertain, and that their association with the breccia had been assumed. Fortunately Ursus deningeri, unknown in post-MIS 12 deposits in Britain (Schreve, 2001), was noted as occurring throughout the breccia by Pengelly (Cook and Jacobi, 1998), and an implied pre-MIS 12 age is also partially supported by recent redating, which suggested correlation of the artefact-bearing breccia with MIS 10 or earlier (Proctor et al., 2005).

The Westbury-sub-Mendip site (Figure 1) has yielded a distinctive early Middle Pleistocene fauna (including Ursus deningeri, Homotherium latidens, and Stephanorhinus hundsheimensis, the latter two species of which are also unknown in post-MIS 12 British deposits). Recent investigations (Andrews et al., 1999) have greatly increased the span of the cave deposits, with Mimomys occurring in the very lowest deposits (with an Early Pleistocene age further supported by reversed polarity evidence), followed by two temperate phases (both containing Arvicola) separated and succeeded by cold climate episodes. (Schreve et al., 1999). Although not easy to differentiate between an interpretation of two interglacials (e.g. MIS 13 and 15) or two warm sub-stages within a single interglacial (Schreve et al., 1999; Preece, 2001), the presence of Microtus gregaloides at Westbury suggests that the site as a whole may be slightly older than Boxgrove (where the M. gregalis form of narrow-skulled vole occurs; Preece et al., 2009). The site is also known for a sparse assemblage of possible artefacts. The 'artefacts' consist of small numbers of flint/chert pieces (Bishop, 1975; Cook, 1999), and are thought to have been washed into the cave from the surface along with other sediments. The status of the artefacts has been much debated (Roe, 1981; Wymer, 1988; Cook, 1999), with Cook (1999) arguing that the flint originated from local sources (although attempts to identity these sources have produced equivocal results), and that pebbles were transformed into pseudo-artefacts through mechanical and thermal fracturing during their introduction into the cave (Cook, 1999; but cf. Wymer, 1988; Schreve et al., 1999). Nonetheless the presence of cut marks on a red deer bone recovered from the upper part of the sequence (Andrews and Ghaleb, 1999) supports a view that at least some of the artefacts are genuine (after Wymer, 1988) and that there was a pre- 
MIS 12 hominin presence in the near vicinity of the site. Current European patterning in the chronological distributions of Arvicola and Mimomys would suggest an MIS 13 and/or 15 age (Preece, 2001; Preece et al., 2009).

\section{Climate and Habitat Preferences}

The early Middle Pleistocene period in Britain has provided key evidence of climatic and environmental preferences from five sites: Boxgrove, Happisburgh 1, High Lodge, Pakefield, and Waverley Wood. In all five cases conditions have been characterised as temperate or cool temperate, although there is also considerable variation between the 'Mediterranean' (cool, wet winters and warm, dry summers) type-climate of Pakefield and the cooler than present day conditions at Happisburgh 1 and High Lodge (Table 5). A mosaic of both open and woodland habitats is evident at all of the sites, with the presence of either/both still and flowing water in both wetter (marshy) and drier (grassland) settings, and a rich array of plant and animal resources available for exploitation. In the case of High Lodge for example, Ashton et al. (1992b) emphasise the availability of aquatic tubers, fish and game birds from the marshy reed-swamps and backwaters, alongside an open corridor (on the floodplain and the river's levees and bars) and river water source for both hominins and horse and elephant herds, as well as deer in the woodlands, and flint cobbles and nodules from the river gravels and local Chalk exposures. However the modelled winter temperatures (Table 5) do question how the hominins coped with the 'overwintering problem' at 50-53' $\mathrm{N}$ (Roebroeks, 2001 describes this as the challenge posed by the 'winter stop' in the environment's productivity in the temperate zone). As the palaeoenvironmental data has been extensively reported elsewhere (Shotton et al., 1993; Roberts and Parfitt, 1998; Coope, 2006; Candy et al., 2006; Holmes et al., in press), it is summarised here in terms of overall regime, reconstructed temperatures, local flora and fauna, habitat and landscape contexts, and the key sources of evidence (Table 5).

Comparison of the British data with reconstructed palaeo-climates for Spanish Early Pleistocene and early Middle Pleistocene sites (Agusti et al., 2009; Table 6) reveals three contrasts of potential significance for understanding hominin climatic tolerances:

1. Although the mean warmest month temperature estimates for Pakefield and Boxgrove overlap with the majority of the Spanish sites containing evidence of a hominin presence, all of the British sites (with the exception of Waverley Wood, for which no data are available) are characterised by sub-freezing mean coldest month temperatures (minimum values), in contrast to the Spanish sites (with the exception of Cal Guardiola).

2. The mean warmest month temperature estimates for Happisburgh 1, Waverley Wood, and High Lodge are lower than, and do not overlap with, any of the Spanish sites with hominin evidence.

3. All of the British sites' temperature estimates are also comparable with, or lower than, those for the site of Cal Guardiola, included by Agusti et al. (2009) within their phase 4: a late Early Pleistocene period characterised by a sharp fall in temperature, although by an increase in precipitation.

Agusti et al. (2009) argued that their Spanish data indicated a clear Early Pleistocene and early Middle Pleistocene association between hominin presence and relatively wet and warm phases, with an accompanying absence of hominins during relatively dry and cold phases. They concluded that human settlement in Western Europe at this time was associated with periods characterised by mild environmental conditions. The British data indicate an early Middle Pleistocene hominin presence on sites where the palaeo-climate was c. $6-9^{\circ} \mathrm{C}$ colder than at the Spanish Early Pleistocene sites (based on average differences between the British and Spanish sites for the minimum and maximum temperature values in the coldest and warmest months). These data also suggest that the British hominins of the early Middle Pleistocene were able to survive in temperatures comparable or worse than those which appear to have been associated with a phase of late Early Pleistocene absence in Spain. Finally the data for the younger British sites (MIS 13/15?) indicate that for the hominins to be over-wintering, they would potentially be facing coldest month temperatures falling several degrees centigrade below freezing (Table 5). There is an interesting contrast here with the older site of Pakefield, where the presence of hippopotamus is likely to suggest winter temperatures above freezing (Stuart and Lister, 2001; Candy et al., 2006; cf. Coope, 2006).

While local variations in hominins' landscape and habitat preferences are extremely difficult to demonstrate for this period, the evidence from the contemporary soil horizon palaeolandscapes at 
Boxgrove and the Valdoe Quarry provide a valuable example (Figure 4). The absence of arboreal and woodland indicator species in the mammalian fauna, the absence of molluscan species with preferred leaf litter habitats, and the molluscan evidence for only localised shady conditions suggests that the immediate Valdoe landscape may have been wetter than the Boxgrove site, possibly seasonally flooded by the River Lavant (Pope et al., 2009). Pope et al. have suggested that the wetter conditions may have resulted in lower game concentrations and more limited hunting opportunities, which combined with the absence of bifaces from both the Valdoe excavations and the quarry's reject heaps led them to conclude that this landscape was perhaps less intensively occupied and less attractive to hominins than the contemporary landscapes at Boxgrove and Slindon. Furthermore the densities of biface finds to the immediate west of the Valdoe Quarry suggest that the palaeo-Levant estuary may have been another preferred location, although its exact relationship to the Slindon Formation remains to be established (Pope et al., 2009).

\section{Material Culture Variability and Patterning}

The archaeology of Britain upto and including early MIS 12 comprises a mixture of in situ landsurfaces and river-rolled artefacts, and while bifaces dominate the lithic artefact record this is at least in part a product of assemblage contexts and sampling histories. It is notable that the oldest site (Pakefield) has produced a small core and flake assemblage, with no evidence of biface technologies, while the wide range of flake tools from High Lodge (woodworking? hide processing?: Ashton et al., $1992 b)$ help to refocus attention away from standard 'biface butchery knife' explanations. The bifaces vary considerably in form, both refuting notions of evolutionary progression (despite the current chronological uncertainties associated with several of the contextual deposits, especially in East Anglia: Tables 2 and 4) and highlighting the roles of raw materials and local traditions.

The nature and age of the Pakefield archaeology raise important questions about the technology of the earliest hominins reaching Britain and northern Europe during the early Middle Pleistocene. At present British biface assemblages from this period are clearly present in MIS 13 (Boxgrove), and more generally are probably limited to the latter half of the early Middle Pleistocene (e.g. MIS 15?early MIS 12?; Waverley Wood, High Lodge, Kent's Cavern?), although the ages of Happisburgh 1 and the Bytham River biface assemblages (e.g. at Warren Hill) remain key points of debate (Sections 2.1.1, 2.1.2.2 and 2.1.2.4; Tables 2 and 4). If the Preece et al. (2009) chronology for Happisburgh 1 is accepted (including an MIS 13/12 age for the Bytham terraces), then the Pakefield evidence may reflect the presence of earlier, non-biface producing, hominins, having maybe 'tracked' favourable Mediterranean-type conditions into northern Europe (Roebroeks, 2005) or perhaps even originating from those areas of north-central Europe in which core and flake technologies are characteristic during the early and later Middle Pleistocene (Bosinski, 1995; Mania, 1995). These early British occupants were then separated by a notable chronological interval from an influx of biface-making hominins around half a million years ago. It is important to note however that the Pakefield assemblage is extremely small to be used to support such conclusions (see also McNabb, 2007, Ch. 1 and 3 concerning the robust identification of non-biface sites and traditions), and/or that local raw material limitations may prosaically explain the simple core and flake working, rather than any distinct cultural traditions (Parfitt, 2008). These interpretations are favoured here (see also Villa, 2001). Furthermore the Lee et al. (2004a) chronology for the Bytham terraces and the Happisburgh till reduces the chronological interval between any suggested core and flake (Pakefield) and biface 'traditions' or 'cultures'. Interestingly, older ages (i.e. pre-MIS 13/15) for the first British bifaces would

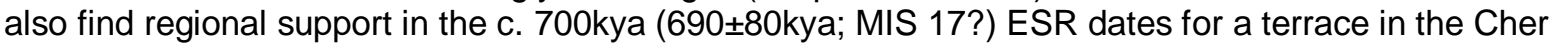
River (Middle Loir Basin, France) that has yielded a biface assemblage (Voinchet et al., in press). Even older bifaces have been claimed from the sites of Solana del Zamborino (c. 750-770kya) and Estrecho del Quípar (c. 900kya) in Spain (Scott and Gibert, 2009).

The well made nature of the bifaces at High Lodge, Boxgrove, and (in part) Warren Hill played a key role in the rejection of evolutionary models of biface development in the 1980s and 1990s. The early Middle Pleistocene biface record provides support for raw material variability models (Ashton and McNabb, 1994; White, 1998), with the Boxgrove and High Lodge bifaces (for which flint raw materials were freshly obtained, at least in part in the case of High Lodge, from Chalk; Ashton, 1992b, 157; Roberts and Parfitt, 1999) in stark contrast to those from Kent's Cavern (compare Figures 7 and 8). This small sample of bifaces is notable for the appearance of the artefacts (Roe, 1981, Fig. 4:4; Cook and Jacobi, 1998, Fig. 12.4), with their relative thickness, minimal flaking, and large proportions of remnant cortex being highly suggestive of raw material conditioning and expedient flaking (see White, 1998). By contrast Wymer (1999) has noted that all of the East Anglian Bytham River biface 
assemblages, occurring within a landscape of available Chalk flint, are dominated by ovate forms, again meeting the predictions of raw material models such as White (1998). However the Warren Hill evidence does suggest that other factors such as local traditions may also have played a role in biface variability: the frequent use of a high quality local Chalk flint of dark/black colour in the second, thicker and 'cruder', of the two potential artefact groups (Roe, 1981; Wymer et al., 1991) is at odds with the predictions of the raw material models.

The archaeological significance of the High Lodge re-assessment concerned the demonstrated presence of both bifaces and cores, flakes and flake tools (Acheulean and Clactonian in the traditional British terminology of the 1930s onwards: O'Connor, 2007) in the vicinity of the site prior to MIS 12, with the resolved chronology confirming that the well-made scrapers (Figure $5 \mathrm{c}$ ) were not Middle Palaeolithic/Mousterian in age, as previously argued (e.g. Evans, 1897; see also Ashton, 1992a). Refitting scatters from the British Museum's excavations have revealed two distinct approaches to flake modification (with the flake blanks produced mainly by alternate platform technique): retouching into carefully prepared scrapers (the cause of the 'Middle Palaeolithic' confusion in the early $20^{\text {th }}$ century); and the removal of further flakes, producing 'flaked flakes' with sharp, durable and slightly concave edges, 'ideal for planning and whittling wood' (Ashton et al., 1992b). While the exact function of these flake tools remains uncertain, their association with High Lodge's spruce-pine woodlands (Table 5) supports a woodworking notion, perhaps linked to the types of spears evident at the later Middle Pleistocene sites of Clacton (Oakley et al., 1977) and Schöningen (Thieme, 2005) and possibly also the construction of rudimentary, archaeological invisible, shelters (see also White, 2006). Shelter (or body?) coverings could have been produced from either woodland vegetation or animal hides, the processing of which is likely to have involved the scrapers found at both High Lodge and Warren Hill. In this context the paucity of flake tools at Boxgrove, particularly at the single event butchery events, is unsurprising, with biface (or unmodified flake)-skinned animal hides (Jones, 1980; Machin et al., 2007) probably being removed elsewhere for scraper-based processing. The exploitation and use of organic resources is also highlighted by the rare antler soft hammers from Boxgrove (Pope, 2003).

The suggestion of shelters and the palaeoenvironmental evidence for cool winters (Section 3; Table 5 ) also raises the question of fire-using behaviours. Evidence is known from this period in the Near East at Gesher Benot Ya'aqov (Goren-Inbar et al., 2004), and from the British later Middle Pleistocene at Beeches Pit during MIS 11 (Preece et al., 2006). There is however no clear British evidence to date from the pre-MIS 12 period, and while many of the Happisburgh 1 site samples also include wood charcoal (Coope, 2006 also noted fragments at Waverley Wood and High Lodge) it has not been possible to distinguish between hominin fire technology and natural woodland fires as the cause (Ashton et al., 2008).

\section{Subsistence Behaviours}

The evidence for hominin subsistence practices in Britain up to early MIS 12 is dominated by Boxgrove (Roberts and Parfitt, 1999; Bello et al., 2009), although limited evidence is also available from Happisburgh 1 (Parfitt, 2005; Ashton et al., 2008) and Westbury-sub-Mendip (a cut mark on a red deer metacarpal; Andrews and Ghaleb, 1999). At Pakefield there is currently no evidence of butchery on the fauna, although this may be due to the post-depositional surface damage on many of the bones (Parfitt, 2008, 132), and there is also no evidence for hominin modifications of the large mammal fauna at Waverley Wood (Shotton et al., 1993; Keen et al., 2006), High Lodge (Stuart, 1992), and Kent's Cavern (Campbell and Sampson, 1971; Straw, 1996). In those cases where evidence is present it indicates the involvement of hominins with large mammal fauna, with direct hunting, rather than confrontational scavenging, being strongly suggested as the mode of access.

Boxgrove has produced extensive evidence for the hominin modification of large mammal fauna, including Ursus deningeri, Cervus elephus, Equus ferus, and Stephanorhinus hundsheimensis (Roberts and Parfitt, 1999, Table 138), consisting of cut marks, chop and scrape marks, and percussion damage (by hammerstone to extract bone marrow). Bello et al. (2009, Table 1) also note the presence of cut-marks on Capreolus capreolus (cf. Roberts and Parfitt, 1999). Of particular note is the evidence for carnivore involvement subsequent to hominin carcass dismemberment (e.g. on a rhinoceros calcaneus), the probable puncture wound in the GTP 17 horse scapula and its parallels with the later MIS 11 spears from Schöningen (Thieme, 2005) and Clacton (Warren, 1911; Oakley et al., 1977), and the range and distribution of activities (skinning, dismemberment, filleting, and marrow bone breakage), which indicate that the carcasses were relatively complete prior to butchery (Roberts and Parfitt, 1999). While a definitive distinction between hunting and confrontational scavenging was 
not drawn by Roberts and Parfitt (1999), the former was favoured on the grounds of the available evidence.

Alongside the cut-marked bison bone found in the Natural History Museum's Savin Collection (Parfitt, 2005), the recent fieldwork at Happisburgh 1 has produced further evidence of humanly-modified bone and the butchery of large and medium-sized mammals, including a rhinoceros rib (disarticulation cut marks), and a roe deer calcaneus and bovid femur (both defleshing marks; Ashton et al., 2008). The femur, and a fragment of bovid mandible, also exhibit lunate fracture scars resulting from marrow extraction (Ashton et al., 2008). Carnivore gnawing is evident on several of the large mammal bones, which along with digestion of the small mammal remains (Ashton et al., 2008) indicates the potential for confrontational scavenging, alongside hunting, as a viable hominin strategy.

\section{Spatial and Landscape Behaviours}

Britain's early Middle Pleistocene archaeological record enables spatial and landscape behaviours to be explored in two contexts: local and exotic raw material use in the Bytham River landscape (Rose, 1987, 1994, 2009; Lewis, 1998; Stephens et al., 2008); and the high resolution artefact signatures of the 'Boxgrove' palaeolandscape (Roberts and Parfitt, 1999; Pope et al., 2009). While the raw material evidence in both of these contexts is strongly suggestive of locally-focused activities, it is clear that 'local' cannot be taken as a synonym for 'simple', with the archaeology of the Westbourne-Arundel Raised Beach highlighting the existence of dynamic, mobile and structured technological systems (Pope, 2004; Pope and Roberts, 2005; Pope et al., 2009).

In East Anglia the southern sweep of the Bytham River, including the flint artefact-dominated sites of High Lodge, Warren Hill, Feltwell (Shrub Hill and Frimstone Quarry), Hockwold-cum-Wilton (Wilton Hill), Brandon Fields, and Lakenheath (Maidscross Hill), flowed along the edge of a Chalk escarpment (Figure 2). Wymer (2001) has highlighted the availability of flint throughout this landscape, both on the escarpment slopes and on the channel-side and mid-channel gravel bars of the river, as an obvious attraction to hominins. In light of such raw material resources it is notable that a small number of the Frimstone Quarry bifaces and other artefacts were made on quartzite pebbles (Figure 6), which make up c. $30 \%$ of the larger clast component of the Feltwell gravel (MacRae, 1999; Hardaker and MacRae, 2000; Wymer, 2001). However the degree of rolling on the Frimstone quartzite artefacts suggests that they have been transported an unknown distance downstream, perhaps from areas where, unlike Frimstone, flint was not locally available or at least not abundant (Hardaker and MacRae, 2000). Following Ashton et al.'s (2006) discussion of riparian landscapes in MIS 11 and their role as major landscape 'routeways', the eastwards turn of the Bytham river through a Chalk gap to the south of Brandon is likely to have acted as a significant pathway between the landscapes to the west, including the English Midlands, and those to the east: the contemporary coastline, the southern North Sea delta, and beyond into continental north-western Europe (Figures 1 and 2). As Wymer (2001) has argued, the presence of this major pre-MIS 12 river floodplain may well explain the relative richness of the East Anglian record at this time in comparison to that of the ancestral Thames.

Upstream from this flint-rich zone the available raw materials of the Bytham River landscape change dramatically. The use of andesite and quartzite is evident at Waverley Wood (Shotton et al., 1993; Keen et al., 2006), in the andesite biface at Rearsby, close to Brooksby (Stephens et al., 2008), and potentially at Pool Farm Pit in Brandon, Warwickshire (Fennell and Shotton, 1977), although there are question marks over the exact provenance of the andesite biface from the latter site (Lang and Keen, 2005). The Waite collection from north-east Warwickshire and south Leicestershire (Saville, 1988; Stephens et al., 2006), which contains a significant component of quartzite artefacts, is likely to contain at least some pre-MIS 12 material from the Midlands region (Shotton, 1988; Wymer, 1999), although full publication of the collection is currently awaited (Lang and Keen, 2005).

While the quartzite artefacts almost certainly reflect immediate use of the locally available fluvial cobbles of the Bytham River's deposits (Keen et al., 2006), the presence of andesite and flint artefacts in the early Middle Pleistocene deposits of the Midlands raises challenging questions concerning raw material sources and acquisition. During recent work at Waverley Wood two andesite blocks were recovered. Petrological analysis indicated a Lake District origin (Keen et al., 2006, 468), as had previously been suggested by Shotton et al. (1993) for the andesite bifaces found in the 1980 s. Hominin transport of such materials over $300 \mathrm{~km}$, either as raw materials or partly worked/finished artefacts, seems very unlikely. This is in light of both the evidence for the use of local 
quartzite at Waverley Wood, and published surveys of lithic transfer distances in the Lower Palaeolithic, which overwhelmingly suggest the use of predominantly 'local' (within $3 \mathrm{~km}$ ) sources (Féblot-Augustins, 1999, Table 2; but cf. Shotton et al., 1993). However there is no clear evidence for the introduction of andesite as pre-MIS 12 glacial erratics, and the exact source of these materials is currently uncertain, although rare andesite cobbles do occur in the basal layers of the Baginton Formation at Waverley Wood (Keen et al., 2006). Recently Bridgland et al. (in press) have also identified andesite sources in the Charnwood Forest, north-west of Leicester (Figure 2), providing further support for a relatively local source. The presence of flint artefacts is more curious, since the raw material only occurs as rare, highly weathered and shattered pebbles within the pre-MIS 12 deposits of the West Midlands area. Fresh flint supplies from Cretaceous Chalk outcrops are some $125 \mathrm{~km}$ to the east (Norfolk) and $100 \mathrm{~km}$ to the south (Oxfordshire), beyond the upper range quoted by Féblot-Augustins (1999, Table 2), although there is no evidence for a glacial origin introducing these materials into the vicinity of the site (Keen et al., 2006).

At a very different scale the analysis of the Boxgrove archaeology has led Pope (2004; Pope and Roberts, 2005) to identify three repeated behavioural signatures: individual knapping scatters, reflecting both biface thinning (e.g. site Q1/A) and re-sharpening activities (Pope and Roberts, 2005); single-event butchery sites (e.g. the GTP 17 horse butchery locality) from which bifaces were habitually removed, despite their introduction, as indicated by re-fitting evidence, in various stages of completion (Pope and Roberts, 2005); and repeatedly visited, favoured localities (e.g. the Q1/B waterhole site), at which large proportions of bifaces were discarded, alongside an atypical occurrence of flake tools, percussors, and antler soft hammers (Pope and Roberts, 2005). The archaeology therefore indicates the preferential discard of bifaces in areas close to freshwater sources near the foot of the Chalk cliff. Since the short transport distances (up to $250 \mathrm{~m}$ ) and the abundance of other types of artefactual material at distances greater than $200 \mathrm{~m}$ (Pope, 2004) would seem to rule out resource tethering, these assemblage variations have been interpreted by Pope and Roberts (2005) as a product of biface transport and structured discard behaviours.

While at Boxgrove the freshwater sources occur at the base of the Chalk cliff, Pope (2004) emphasises that it is the freshwater static resources (after Ashton, 1998) rather than the cliff which is the key structuring element. This structuring resulted in high density artefact (biface-dominated) patches in association with fixed resources (freshwater, raw materials, game aggregations, plant foods), and diffuse scatters relating to short-term activities exploiting mobile and unpredictable game resources (Pope, 2004). While the high quality of the Boxgrove evidence limits the range of potential parallels, the later MIS 9 palaeolandscape at Soucy (Lhomme, 2007) has revealed comparable patterns in the mobility of bifaces, while Hallos (2004) has similarly highlighted artefact transport and dynamic technological systems at the later Middle Pleistocene sites of Beeches Pit (MIS 11) and Ferme de L'Epinette (early MIS 10). More speculatively Pope and Roberts (2005) have further argued that the structured nature of the Boxgrove materials not only implies their selective re-location, re-use, and discard by hominins, but also that the hominin individuals actively engaged with their own archaeological traces, and that they possessed a 'history'.

The Valdoe Quarry has provided further evidence for the transport and modification of bifaces within the 'Boxgrove' palaeolandscape (Pope et al., 2009). With the majority of the Valdoe artefacts recovered from the Slindon Soil Bed palaeosol (Table 3), Pope et al. have suggested that their absence from the inter-tidal silts of the Slindon Silt Member (Table 3) may be due to the distances of all but one of the Valdoe excavation areas from the buried cliff-line (greater than $100 \mathrm{~m}$, which is the upper limit distance from the cliff for the in situ knapping scatters found in the inter-tidal silts at Boxgrove). A limited degree of clustering in the palaeosol artefacts, combined with technological similarities, suggested in situ spreads of late stage biface thinning débitage in the palaeosol, with existing bifaces undergoing short episodes of tip or edge modification (Pope et al., 2009). In contrast the zone immediately adjacent to the cliff (represented by artefacts within the head gravels of the Eartham Upper Gravel Member; Table 3) was characterised by larger proportions of primary débitage and therefore indicated the initial stages of biface manufacture. The Valdoe Quarry palaeosol archaeology is therefore highly reminiscent of the first of Pope's repeated behavioural signatures at Boxgrove (low density, individual knapping scatters reflecting biface thinning and/or re-sharpening):

"The impression is given that small groups of individuals were pausing within an undifferentiated part of the landscape en route between fixed-resource locales (Ashton et al., 1998) and that individuals within the group were modifying bifaces being carried within them." 
(Pope et al., 2009, 258)

\section{Discussion and Conclusions}

Roebroeks (2001) has argued that the persistent occupation of Europe, in particular northern Europe, after c. 500kya would have involved the solving of the 'overwintering problem of the temperate zone' by hunting and eating animals, a strategy which also incorporated various other components, including social co-operation, food exchange, risk sharing, and knowledge transmission. Does the British early Middle Pleistocene record provide evidence for a persistent or semi-persistent occupation and for the presence or absence of such strategies prior to MIS 12 ?

The record is frustratingly undecided at present, in particular with regard to the chronologies of the post-Pakefield archaeology, which creates ongoing difficulties in 'getting the pattern right' (Roebroeks, 2006). A Preece et al. (2009)-influenced model, with the bulk of the well provenanced artefacts dating to MIS 13 and early MIS 12, continues to strongly support the 'modified short chronology' (Roebroeks and van Kolfschoten, 2004; Dennell and Roebroeks, 1996; Roebroeks, 2001, 2006), with a major change in the character and richness of the archaeology to the north of the Alps and the Pyrenees after around 500-600kya. Interestingly, the later Middle Pleistocene settlement history models of Ashton and Lewis (2002) and, less clearly, Ashton and Hosfield (in press) suggest an occupation 'peak' between MIS 13-10 before a gradual decline. The richness of that MIS 13-10 record (occurring for the most part despite the inconveniences to movement into Britain introduced by the probable breaching of the Strait of Dover at c. 450kya: Gibbard, 1995) indicates the first significant archaeological presence in Britain, and is perhaps further indirect evidence in support of the major behavioural shifts argued to occur by Gamble (2009) and Roebroeks (2006) around this time. The regionally variable archaeological signature prior to MIS 12 (in particular the apparent paucity of material from the substantial Colchester Formation deposits in the lower reaches of the pre-diversion Thames) would also seem to support a highly sporadic, patchy presence prior to the very end of the early Middle Pleistocene. It is certainly in contrast to the post-MIS 12 period, where the MIS 11 archaeological records of the Thames, Solent and East Anglian rivers are comparably rich (Wymer, 1999; McNabb, 2007) and seem to support the 'fast' occupation (geologically-speaking) of Dennell and Roebroeks (1996).

In contrast the Bytham terrace model chronology and Happisburgh 1 age of Lee et al. (2004a) offers more of a challenge to Roebroeks' $(2006,428)$ assertion that "the Pakefield evidence underlines the ecological signal of the short chronology". While it obviously doesn't change the palaeoenvironmental reconstructions for Pakefield itself, the increased ages for the Bytham River biface assemblages and the Happisburgh 1 archaeology (into MIS 15, predominantly, and MIS 17; Tables 2 and 4) are suggestive of a more substantial hominin presence during earlier parts of the early Middle Pleistocene. In other words, while the Pakefield finds might still indicate a short-lived hominin shift northwards in line with a temporary expansion of a familiar 'Mediterranean' habitat (Roebroeks, 2005, 2006), 2,000 bifaces from Warren Hill deposits of pre-MIS 13 age may indicate a more persistent presence over a longer span of the early Middle Pleistocene (although this would undoubtedly be a presence interrupted by the severe conditions of the glacial stages, especially MIS 16). The need for resolution of the current geochronological debates should be apparent.

Moving away from the broad-scale record, what does the higher resolution data indicate? Dominant and co-operative hunting of large mammals is strongly suggested by Boxgrove for late MIS 13 (Roberts and Parfitt, 2009; cf. Roebroeks, 2006). Unfortunately however there is currently little direct data on hunting behaviours in the preceding stages of the early Middle Pleistocene. The detailed palaeoenvironmental evidence for selected aspects of Britain's pre-MIS 12 archaeology are strongly suggestive of temperate and cool-temperate conditions and of mosaic environments providing a diverse wealth of potential resources (including the 'invisible' diet: plant foods, eggs, and groundnesting water birds for example), although this may partly be a preservation bias. The modelled coldest month temperatures (Table 5) highlight Roebroeks' (2006) 'overwintering' challenge, and yet there is evidence that the hominins of MIS 13/15 were capable of surviving in cooler climates (on both seasonal and perhaps longer timescales) than the 'Costa del Cromer' of Pakefield (Roebroeks, 2005). This includes the evidence for in situ artefacts in the Boxgrove cold climate gravels and, to a lesser extent, the cooler than present-day summer and winter temperatures at High Lodge, Waverley Wood and Happisburgh 1, and the possible evidence for more 'continental' conditions (i.e. warm, wet summers and severely cold winters) at Boxgrove. What is certainly clear (Table 6) is that the hominins that reached Britain towards the end of the early Middle Pleistocene were able to survive, at least 
sufficiently to become archaeologically visible, summer temperatures typically cooler than those preferred by the earliest occupants of the western Mediterranean during the Early Pleistocene (Agusti et al., 2009). As with so much of the Lower (and Middle) Palaeolithic record however (see also White, 2006), direct evidence of the ability of hominins to cope in temperate and cool-temperate climate winters remains unknown, despite the possibility that the flake tools of High Lodge and elsewhere are an enigmatic indicator of winter-surviving technologies and behaviours such as shelters, clothing and/or fire.

Given the connection with the continental landmass throughout the early Middle Pleistocene, seasonal migration should also be considered as a potential survival strategy option for hominins faced by temperate or cool climate winters. Roebroeks (2006) has previously argued with reference to comparative data from carnivores and living hunter-gatherers that the first Europeans to move north of the major mountain ranges were hunters, operating over large areas. Seasonal movement could/would be a part of such large-scale hunting strategies. Yet while the British record provides probable evidence for hunting (Boxgrove), much of the landscape/raw material evidence are suggestive of locally-focused activities (the 'local hominin network' of Gamble, 1996, 1999) and the use of immediately available lithic sources, whether 'good' (Boxgrove) or 'bad' (Kent's Cavern and Pakefield). However simple energy economizing concerns, particularly in a biface-dominated technology, may limit the potential of lithic data for reconstructing the size of hunting areas (i.e. a hominin might locally acquire/knap/discard raw materials at numerous locations within a larger hunting area). Moreover the available British data generally deals in 'generic' flint, and regional-scale comparisons (e.g. between the Midland and East Anglian sections of the Bytham River), as opposed to the specific lithic transfer distances of Féblot-Augustins (1999). There is the intriguing case of the flint and andesite (but cf. Bridgland et al., in press) artefacts of the Midlands, although a cautious interpretation would highlight the use of rare erratics or unrecognised local sources, rather than seeing these artefacts as far-transported items and a rare archaeological glimpse into the 'large' hunting areas of Roebroeks (2006).

Given these understandable difficulties in detecting evidence for mobility and 'winter technologies', what can be teased from the most robust component of the archaeological record: the lithic artefacts? Certainly the re-sharpening scatters of Boxgrove and the Valdoe Quarry may be a valuable insight into a world of curated, as opposed to immediately made, used, and discarded (Gamble, 1999), bifaces, and the differential use of micro-habitats across the 'Boxgrove' palaeolandscape. Such a curated technology would logically seem to be a component of a highly mobile hunting strategy, in which the availability of good quality (or indeed any quality) raw materials for tool-making when needed, could not be guaranteed. Yet such fine-grained archaeological records are the exception not the rule, and in their absence the lithic record too is frequently enigmatic. Although Britain's postPakefield early Middle Pleistocene biface assemblages reveal considerable local flexibility (e.g. in form, raw material and quality of flaking), the overall impression is of a biface-dominated technology (although a wider technological repertoire is suggested at High Lodge and the Boxgrove waterhole; Ashton, 1992b; Pope and Roberts, 2005). The bifaces suggest that broadly similar hominin behaviours, at least as expressed in lithic technology, were deployed across a range of habitats and environments (the generic or transferable skills of Gamble, 1999). How does this tally with the seemingly complex behaviours of the 'Boxgrove' palaeolandscape?

Roebroeks (2006) has argued that the large hunting areas required to resolve the 'overwintering problem', combined with the larger bodies and higher trophic levels of Middle Pleistocene hominins (inferred from fossil evidence and the Middle Pleistocene encephalisation), would logically result in low population densities, relative to modern humans. These low densities would have potentially negative implications for cumulative cultural evolution, as suggested by Heinrich (2004; see Roebroeks, 2006 for a fuller discussion of this point). Heinrich (2004) proposes that small populations lead to the degradation and loss of complex skills, due to the often imperfect nature of the learning process. As Roebroeks (2006) argues, such an explanation may help to explain the paradox between the evidence for complex Middle Pleistocene hominin behaviours (e.g. knowledge transmission concerning stone and organic artefact fabrication, and surviving in wide-ranging habitats through the hunting of large, dangerous mammals; all of which are seen in the pre-MIS 12 British record) on one hand, and the long-term stability (e.g. the prevalence of Acheulean bifaces both prior to and after MIS 12 ) and absence of the 'ratchet effect' on the other (Mithen, 1999). 
While the record is far from perfect, the majority of the British early Middle Pleistocene archaeology appears to fall into Roebroeks' $(2001,429)$ third category of European colonisation: "a more permanent presence in Europe, including its higher latitudes, from about 500-600ka onward". Pakefield would seem to remain a sole, well provenanced, example of Roebroeks' $(2006,428)$ "thinly spread presence in southern and occasionally Atlantic western Europe between 1 and $0.6 \mathrm{Ma}$ ", the product of a temporary expansion in Mediterranean-type habitats and the early hominin range. At present it is not possible to say from the archaeological evidence whether the Pakefield hominins had adopted Roebroeks' (2006) strategies for 'overwintering', but the apparent gap before humans next returned suggests that they may not have.

In conclusion:

1. The British early Middle Pleistocene archaeological record has been greatly enriched over the last twenty-five years (cf. Wymer, 1988; Roberts et al., 1995), as a result of new excavations and fieldwork (e.g. Ashton et al., 1992; Shotton et al., 1993; Roberts and Parfitt, 1999; Parfitt et al., 2005; Keen et al., 2006; Ashton et al., 2008), and/or the contextualisation of older collections (e.g. Ashton et al., 1992a; Bridgland et al., 1995; Cook and Jacobi, 1998; Andrews et al., 1999).

2. The earliest hominin presence in Britain occurs at Pakefield (a small core and flake assemblage; MIS 19 or 17; Parfitt et al., 2005), followed by a series of biface assemblages associated primarily with the Bytham River and the Westbourne-Arundel raised beach (Wymer, 1985, 1999; Roberts and Parfitt, 1999; McNabb, 2007; Pope et al., 2009), with occasional findspots and sites in the Thames and Solent River systems and elsewhere (Wymer, 1999; McNabb, 2007).

3. The ages of the Bytham River terrace assemblages and the Happisburgh 1 site have been widely debated (Lee et al., 2004a; Preece and Parfitt, 2008; Rose, 2009; Preece et al., 2009) and are central to the character of the post-Pakefield archaeological record.

4. Hominin habitats (Table 5) are characterised by temperate or cool-temperate climates typically cooler than the present (cf. Pakefield) and mosaic environments, providing a wide range of potential resources (freshwater, animal and plant foods, and lithic and organic raw materials).

5. Subsistence evidence is restricted to a very small number of sites, but Boxgrove provides strong evidence for direct and probably co-operative hunting in MIS 13 (Roberts and Parfitt, 1999).

6. Local raw materials were a key factor in biface variability (contrast Kent's Cavern and Boxgrove: Roe, 1981; Cook and Jacobi, 1998; Roberts and Parfitt, 1999), although there is also some evidence for local, short-lived traditions (e.g. Warren Hill: Wymer et al., 1991). While biface technologies dominate, the High Lodge flake tools are suggestive of a broader technological repertoire (Ashton, 1992b).

7. The British record, following the chronology of Preece et al. (2009) for Happisburgh 1 and MIS 13/early MIS 12 ages for the Bytham terraces (Preece and Parfitt, 2008), continues to support the 'modified short chronology' model for the occupation of northern Europe (Dennell and Roebroeks, 1996; Roebroeks 2001), with a more permanent presence and an accompanying behavioural shift after 500-600kya (Roebroeks, 2006; Gamble, 2009; cf. Rose, 2009).

8. An increase in the early Middle Pleistocene ages of the key artefact-bearing terraces of the Bytham and the Solent Rivers, and/or further discoveries from the Cromer Forest-bed Formation, would present new challenges to the 'modified short chronology'.

Acknowledgements

My thanks to Nick Ashton, Simon Lewis, Matthew Pope, and John McNabb for valuable discussions on some of the issues discussed in this paper, and also to Matt for providing a pre-publication copy of his and his colleagues' Valdoe Quarry paper. The paper has also benefitted greatly from the comments of two anonymous reviewers. Thanks to Nick Ashton, Terry Hardaker, Mark Roberts, and Derek Roe, for their permissions to reproduce previous illustrations as Figures 5-8 respectively. Finally this paper has inevitably drawn heavily upon the excellent and continuing research of numerous colleagues in the British and European Palaeolithic and Quaternary Science communities: any misrepresentations or errors are of course my own.

References 
Allen, L.G., Gibbard, P.L., 1993. Pleistocene evolution of the Solent river of southern England. Quaternary Science Reviews 12, 503-528.

Agustí, J., Blain, H-A., Cuenca-Bescós, G., Bailon, S., 2009. Climate forcing of first hominin dispersal in Western Europe, Journal of Human Evolution 57, 815-821.

Andrews, P., Ghaleb, B., 1999. Taphonomy of the Westbury Cave bone assemblages. In: Andrews, P., Cook, J., Currant, A., Stringer, C.B. (Eds.), Westbury Cave: The Natural History Museum Excavations 1976-1984. Western Academic and Specialist Press, Bristol, pp. 87-126.

Andrews, P., Cook, J., Currant, A., Stringer, C.B. (Eds.), 1999. Westbury Cave: The Natural History Museum Excavations 1976-1984. Western Academic and Specialist Press, Bristol.

Arkell, W.J., 1947. The Geology of Oxford. Clarendon, Oxford.

Ascenzi, A., Mallegni, F., Manzi, G., Segre, A.G., Segre Naldini, E., 2000. A re-appraisal of Ceprano calvaria affinities with Homo erectus, after the new reconstruction. Journal of Human Evolution 39, 443-450.

Ashton, N.M., 1992a. Historical background and description of excavations 1962-8 and 1988. In: Ashton, N.M., Cook, J., Lewis, S.G., Rose, J. (Eds.), High Lodge: Excavations by G. de G. Sieveking, 1962-68, and J. Cook, 1988. British Museum Press, London, pp. 25-50.

Ashton, N.M., 1992b. The High Lodge flint industries. In: Ashton, N.M., Cook, J., Lewis, S.G., Rose, J. (Eds.), High Lodge: Excavations by G. de G. Sieveking, 1962-68, and J. Cook, 1988. British Museum Press, London, pp. 124-163.

Ashton, N.M., 1998. The spatial distribution of the flint artefacts and human behaviour. In: Ashton, N.M., Lewis, S.G., Parfitt, S.A. (Eds.), Excavations at the Lower Palaeolithic site at East Farm, Barnham, Suffolk 1989-94. British Museum Press (British Museum Occasional Paper No. 125), London, pp. 251-258.

Ashton, N.M., Hosfield, R., in press. Mapping the human record in the British early Palaeolithic: evidence from the Solent River system. Journal of Quaternary Science.

Ashton, N.M., Lewis, S.G., 2002. Deserted Britain: Declining Populations in the British Late Middle Pleistocene. Antiquity 76, 388-396.

Ashton, N.M., McNabb, J., 1992. The interpretation and context of the High Lodge industries. In: Ashton, N.M., Cook, J., Lewis, S.G., Rose, J. (Eds.), High Lodge: Excavations by G. de G. Sieveking, 1962-68, and J. Cook, 1988. British Museum Press, London, pp. 164-168.

Ashton, N.M., McNabb, J., 1994. Bifaces in Perspective. In: Ashton, N.M., David, N. (Eds.), Stories in Stone. Lithic Studies Society (Occasional Paper No. 4), London, pp. 182-91.

Ashton, N.M., Cook, J., Lewis, S.G., Rose, J. (Eds.), 1992a. High Lodge: Excavations by G. de G. Sieveking, 1962-68, and J. Cook, 1988. British Museum Press, London.

Ashton, N.M., Lewis, S.G., Rose, J., 1992b. The Summary. In: Ashton, N.M., Cook, J., Lewis, S.G., Rose, J. (Eds.), High Lodge: Excavations by G. de G. Sieveking, 1962-68, and J. Cook, 1988. British Museum Press, London, pp. 169-179.

Ashton, N.M., Lewis, S.G., Parfitt, S.A. (Eds.), 1998. Excavations at the Lower Palaeolithic site at East Farm, Barnham, Suffolk 1989-94. British Museum Press (British Museum Occasional Paper No. 125), London.

Ashton, N.M., Lewis, S.G., Parfitt, S.A., White, M.J., 2006. Riparian landscapes and human habitat preferences during the Hoxnian (MIS 11) Interglacial. Journal of Quaternary Science 21, 497505.

Ashton, N.M., Parfitt, S.A., Lewis, S.G., Coope, G.R., Larkin, N., 2008. Happisburgh Site 1 (TG388307). In: Candy, I., Lee, J.R., Harrison, A.M. (Eds.), The Quaternary of Northern East Anglia Field Guide. Quaternary Research Association, London, pp. 151-156.

Banham, P.H., Gibbard, P.L., Lunkka, J.P., Parfitt, S.A., Preece, R.C., Turner, C., 2001. A critical assessment of 'a new glacial stratigraphy for eastern England'. Quaternary Newsletter 93, 514.

Bassinot, F.C., Labeyrie, L.D., Vincent, V., Quidelleur, X., Shackleton, N.J., Lancelot, Y., 1994. The astronomical theory of climate and the age of the Brunhes-Matuyama magnetic reversal. Earth and Planetary Science Letters 126, 91-108.

Bello, S.M., Parfitt, S.A., Stringer, C., 2009. Quantitative micromorphological analyses of cut marks produced by ancient and modern handaxes. Journal of Archaeological Science 36, 18691880.

Bermúdez de Castro, J.M., Arsuaga, J.L., Carbonell, E., Rosas, A., Martínez, I., Mosquera, M., 1997. A hominid from the Lower Pleistocene of Atapuerca: possible ancestor to Neanderthals and Modern Humans. Science 276, 1392-1395.

Bintanja, R., van der Wal, R.S.W., Oerlemans, J., 2005. Modelled atmospheric temperatures and global sea levels over the past million years. Nature 437, 125-128. 
Bishop, M.J., 1975. Earliest record of man's presence in Britain. Nature 253(5487), 95-97.

Bosinski, G., 1995. The earliest occupation of Europe: Western Central Europe. In: Roebroeks, W., van Kolfschoten, T. (Eds.), The Earliest Occupation of Europe. Proceedings of the European Science Foundation Workshop at Tautavel (France) 1993. Leiden University Press, Leiden, pp. 103-128.

Bowen, D.Q., Rose, J., McCabe, A.M., Sutherland, D.G., 1986. Correlation of Quaternary glaciations in England, Ireland, Scotland and Wales. Quaternary Science Reviews 5, 299-340.

Bowen, D.Q. (Ed.), 1999. A Revised Correlation of Quaternary Deposits in the British Isles. Geological Society of London (Special Report No. 23), London.

Briant, R.M., Schwenninger, J.-L., 2009. Solent river gravels at Badminston Farm, Hampshire SU 463 019. In: Briant, R.M., Bates, M.R., Hosfield, R.T., Wenban-Smith, F.F. (Eds.), The Quaternary of the Solent Basin and West Sussex Raised Beaches. Quaternary Research Association, London, pp. 189-97.

Briant, R.M., Bates, M.R., Schwenninger, J.-L., Wenban-Smith, F.F., 2006. An optically stimulated luminescence dated Middle to Late Pleistocene fluvial sequence from the western Solent Basin, southern England. Journal of Quaternary Science 21(5), 507-523.

Briant, R.M., Wenban-Smith, F.F., Schwenninger, J.-L., 2009. Solent river gravels at Barton on Sea, Hampshire SZ 230 930. In: Briant, R.M., Bates, M.R., Hosfield, R.T., Wenban-Smith, F.F. (Eds.), The Quaternary of the Solent Basin and West Sussex Raised Beaches. Quaternary Research Association, London, pp. 161-170.

Bridgland, D.R., 1994. Quaternary of the Thames. Chapman \& Hall (Geological Conservation Review Series), London.

Bridgland, D.R., 2001. The Pleistocene Evolution and Palaeolithic Occupation of the Solent River. In: Wenban-Smith, F.F., Hosfield, R.T. (Eds.), Palaeolithic Archaeology of the Solent River. Lithic Studies Society, London, pp. 15-25.

Bridgland, D.R., Lewis, S.G., Wymer, J.J., 1995. Middle Pleistocene stratigraphy and archaeology around Mildenhall and Icklingham, Suffolk: report on the Geologists' Association Field Meeting, 27 June, 1992. Proceedings of the Geologists' Association 106, 57-69.

Bridgland, D., Maddy, D., Bates, M., 2004. River terrace sequences: templates for Quaternary geochronology and marine-terrestrial correlation. Journal of Quaternary Science 19, 203218.

Bridgland D.R., Howard, A.J., White, M.J., White, T.S., in press. Quaternary of the Trent. Oxbow, Oxford.

Campbell, J.B., Sampson, C.G., 1971. A New Analysis of Kent's Cavern, Devonshire, England. University of Oregon (Anthropology Papers No. 3), Eugene.

Candy, I., Rose, J., Lee, J.R., 2006. A seasonally 'dry' interglacial climate in eastern England during the early Middle Pleistocene: palaeopedological and stable isotopic evidence from Pakefield, UK. Boreas 35, 255-265.

Candy, I., Lee, J.R., Harrison, A.M. (Eds.), 2008. The Quaternary of Northern East Anglia Field Guide. Quaternary Research Association, London.

Carbonell, E., Rodríguez, X.P., 2006. The first human settlement of Mediterranean Europe. C. R. Palevol 5, 291-298.

Carbonell, E., Bermúdez de Castro, J.M., Arsuaga, J.L., Díez, J.C., Rosas, A., Cuenca-Bescós, G., Sala, R., Mosquera, M., Rodríguez, X.P., 1995. Lower Pleistocene hominids and artifacts from Atapuerca-TD6 (Spain). Science 269, 826-830.

Carbonell, E., Bermúdez de Castro, J.M., Parés, J.M., Perez-González, A., Cuenca-Bescós, G., Ollé, A., Mosquera, M., Huguet, R., van der Made, J., Rosas, A., Sala, R., Vallverdú, J., García, N., Granger, D.E., Martinón-Torres, M., Rodríguez, X.P., Stock, G.M., Vergès, J.M., Allué, E., Burjachs, F., Cáceres, I., Canals, A., Benito, A., Díez, C., Lozano, M., Mateos, A., Navazo, M., Rodríguez, J., Rosell, J., Arsuaga, J.L., 2008. The first hominin of Europe. Nature 452(7186), 465-469.

Clayton, K.M., 2000. Glacial erosion of the Wash and Fen basin and the deposition of the chalky till of eastern England. Quaternary Science Reviews 19, 811-822.

Cook, J., 1999. Description and analysis of the flint finds from Westbury Cave. In: Andrews, P., Cook, J., Currant, A., Stringer, C.B. (Eds.), Westbury Cave: The Natural History Museum Excavations 1976-1984. Western Academic and Specialist Press, Bristol, pp. 211-274.

Cook, J., Jacobi, R., 1998. Observations on the Artefacts from the Breccia at Kent's Cavern. In: Ashton, N.M., Healy, F., Pettitt, P. (Eds.), Stone Age Archaeology: Essays in Honour of John Wymer. Oxbow Books (Oxbow Monograph 102 \& Lithic Studies Society Occasional Paper No. 6), London, pp. 77-89. 
Coope, G.R., 1992. The High Lodge insect fauna. In: Ashton, N.M., Cook, J., Lewis, S.G., Rose, J. (Eds.), High Lodge: Excavations by G. de G. Sieveking, 1962-68, and J. Cook, 1988. British Museum Press, London, pp. 117-9.

Coope, G.R., 2006. Insect faunas associated with Palaeolithic industries from five sites of pre-Anglian age in central England. Quaternary Science Reviews 25, 1738-1754.

Dennell, R., Roebroeks, W., 1996. The earliest colonization of Europe: the short chronology revisited. Antiquity $70,535-542$.

Despriée, J., Gageonnet, R., Voinchet, P., Bahain, J-J., Falguères, C., Varache, F., Courcimault, G., Dolo, J-M., 2006. Une occupation humaine au Pléistocène inférieur sur la bordure nord du Massif central. C. R. Palevol 5, 821-828.

Evans, J., 1897. The Ancient Stone Implements, Weapons and Ornaments of Great Britain ( $2^{\text {nd }}$ edition). Longman, London.

Féblot-Augustins, J., 1999. Raw material transport patterns and settlement systems in the European Lower and Middle Palaeolithic: continuity, change and variability. In: Roebroeks, W., Gamble, C.S. (Eds.), The Middle Palaeolithic Occupation of Europe. University of Leiden, Leiden, pp. 194-214.

Fennell, J.F.M., Shotton, F.W., 1977. A newly discovered handaxe from Brandon, Warwickshire. Proceedings of the Coventry and District Natural History and Scientific Society 5(1), 15-17.

Gamble, C.S., 1996. Hominid Behaviour in the Middle Pleistocene: an English Perspective. In: Gamble, C.S., Lawson, A.J. (Eds.), The English Palaeolithic Reviewed. Wessex Archaeology Ltd., Salisbury, pp. 61-71.

Gamble, C.S., 1999. The Palaeolithic Societies of Europe. Cambridge University Press, Cambridge.

Gamble, C.S., 2009. Human Display and Dispersal: A Case Study from Biotidal Britain in the Middle and Upper Pleistocene. Evolutionary Anthropology 18, 144-156.

Gibbard, P.L., 1979. Middle Pleistocene drainage in the Thames Valley. Geological Magazine 116(1), 35-44.

Gibbard, P.L., 1982. Terrace stratigraphy and drainage history of the Plateau Gravels of north Surrey, south Berkshire and north Hampshire, England. Proceedings of the Geologists' Association 93(4), 369-384.

Gibbard, P.L., 1985. The Pleistocene History of the Middle Thames Valley. Cambridge University Press, Cambridge.

Gibbard, P.L., 1994. The Pleistocene History of the Lower Thames Valley. Cambridge University Press, Cambridge.

Gibbard, P.L., 1995. The formation of the Strait of Dover. In: Preece, R.C. (Ed.), Island Britain: A Quaternary Perspective. Geological Society (Special Publication 96), London, pp. 15-26.

Gibbard, P.L., 2007. Palaeogeography: Europe cut adrift. Nature 448, 259-260.

Gibbard, P.L., Moscariello, A., Bailey, H.W., Boreham, S., Koch, C., Lord, A.R., Whittaker, J.E., Whiteman, C.A., 2008. Comment: Middle Pleistocene sedimentation at Pakefield, Suffolk, England. Journal of Quaternary Science 23: 85-92.

Gibbard, P.L., Pasanen, A.H., West, R.G., Lunkka, J.P., Boreham, S., Cohen, K.M., Rolfe, C., 2009. Late Middle Pleistocene glaciation in East Anglia, England. Boreas 38, 504-528.

Goren-Inbar, N., Alperson, N., Kislev, M.E., Simchoni, O., Melamed, Y., Ben-Nun, A., Werker, E., 2004. Evidence of Hominin Control of Fire at Gesher Benot Ya aqov, Israel. Science 304(5671), 725-727.

Grün, R., Schwarcz, H.P., 2000. Revised open-system U-series/ESR age calculations for teeth from Stratum C at the Hoxnian Interglacial type locality, England. Quaternary Science Reviews 19, $1151-1154$.

Gupta, S., Collier, J.S., Palmer-Felgate, A., Potter, G., 2007. Catastrophic flooding origin of shelf valley systems in the English Channel. Nature 448, 342-345.

Hallos, J., 2004. Artefact dynamics in the Middle Pleistocene: implications for hominid behaviour. In: Walker, E.A., Wenban-Smith, F.F., Healy, F. (Eds.), Lithics in Action: Papers from the Conference Lithic Studies in the Year 2000. Oxbow Books (Lithic Studies Society Occasional Paper No. 8), Oxford, pp. 26-37.

Hamblin, R., Moorlock, B., Rose, J., 2000. A New Glacial Stratigraphy for Eastern England. Quaternary Newsletter 92, 35-43.

Hamblin, R.J.O., Moorlock, B.S.P., Rose, J., Lee, J.R., Riding, J.B., Booth, S.J., Pawley, S.M., 2005. Revised pre-Devensian glacial stratigraphy in Norfolk, England, based on mapping and till provenance. Netherlands Journal of Geosciences 84, 77-85.

Hardaker, T., MacRae, R.J., 2000. A lost river and some Palaeolithic surprises: new quartzite finds from Norfolk and Oxfordshire. Lithics: The Newsletter of the Lithic Studies Society 21, 52-59. 
Heinrich, J., 2004. Demography and cultural evolution: how adaptive cultural processes can produce maladaptive losses - the Tasmanian case. American Antiquity 69, 197-214.

Hoare, P.G., Larkin, N.R., Connell, E.R., 2006. The first appearance of Norwegian indicator erratics in the glacial succession of Northeast Norfolk. Quaternary Newsletter 108, 6-13.

Holmes, J.A., Atkinson, T., Darbyshire, D.P.F., Horne, D.J., Joordens, J., Roberts, M.B., Sinka, K.J., Whittaker, J.E., in press. Middle Pleistocene climate and hydrological environment at the Boxgrove hominin site (West Sussex, UK) from ostracod records. Quaternary Science Reviews.

Howard, A.J., Bridgland, D.R., Knight, D., McNabb, J., Rose, J., Schreve, D.C., Westaway, R., White, M.J., White, T.S., 2007. The British Pleistocene fluvial archive: East Midlands drainage evolution and human occupation in the context of the British and NW European record. Quaternary Science Reviews 26, 2724-2737.

Hunt, C.O., 1992. Pollen and algal microfossils from the High Lodge clayey-silts. In: Ashton, N.M., Cook, J., Lewis, S.G., Rose, J. (Eds.), High Lodge: Excavations by G. de G. Sieveking, 196268, and J. Cook, 1988. British Museum Press, London, pp. 109-15.

Jones, P., 1980. Experimental butchery with modern stone tools and its relevance for Palaeolithic archaeology. World Archaeology 12, 153-165.

Keen, D.H., 1999. The chronology of Middle Pleistocene ('Wolstonian') events in the English Midlands. In: Andrews, P., Banham, P. (Eds.), Late Cenozoic environments and hominid evolution: a tribute to Bill Bishop. Geological Society, London, pp. 159-168.

Keen, D.H., Hardaker, T., Lang, A.T.O., 2006. A Lower Palaeolithic industry from the Cromerian (MIS 13) Baginton Formation of Waverley Wood and Wood Farm Pits, Bubbenhall, Warwickshire, UK. Journal of Quaternary Science 21(5), 457-470.

Lang, A.T.O., Keen, D.H., 2005. 'At the Edge of the World...' Hominid Colonisation and the Lower and Middle Palaeolithic of the West Midlands. Proceedings of the Prehistoric Society 71, 63-83.

Lee, J.R., Rose, J., Hamblin, R.J.O., Moorlock, B.S.P., 2004a. Dating the earliest lowland glaciation of eastern England: the pre-Anglian early Middle Pleistocene Happisburgh Glaciation. Quaternary Science Reviews 23, 1551-1566.

Lee, J.R., Booth, S.J., Hamblin, R.J.O., Jarrow, A.M., Kessler, H., Moorlock, B.S.P., Morigi, A.N., Palmer, A., Pawley, S.J., Riding, J.B., Rose, J., 2004b. A new stratigraphy for the glacial deposits around Lowestoft, Great Yarmouth, North Walsham and Cromer, East Anglia, UK. Bulletin of the Geological Society of Norfolk 53, 3-60.

Lee, J.R., Rose, J., Candy, I., Barendregt, R.W., 2006a. Sea-level changes, river activity, soil development and glaciation around the western margins of the southern North Sea Basin during the Early and early Middle Pleistocene: evidence from Pakefield, Suffolk, UK. Journal of Quaternary Science 21, 155-179.

Lee, J.R., Moorlock, B.S.P., Rose, J., Hamblin, R.J.O., Pawley, S.M., Jarrow, A.M., 2006b. A reply to Hoare et al. 2006 - The first appearance of Norwegian indicator erratics in the glacial succession of Northeast Norfolk, eastern England, UK. Quaternary Newsletter 109, 22-26.

Lee, J.R., Rose, J., Candy, I., Barendregt, R.W., Moorlock, B.S.P., Riding, J.B., Hamblin, R.J.O., 2008a. Reply: Middle Pleistocene sedimentation at Pakefield, Suffolk, England. Journal of Quaternary Science 23(1), 93-98.

Lee, J.R., Rose, J., Riding, J.B., Moorlock, B.S.P., Hamblin, R.J.O., 2008b. Happisburgh Cliffs (TG 380 312): Glacial lithostratigraphy, till provenance and ice-marginal deposits. In: Candy, I., Lee, J.R., Harrison, A.M. (Eds.), The Quaternary of Northern East Anglia Field Guide. Quaternary Research Association, London, pp. 137-150.

Lewis, S.G., 1992. High Lodge - stratigraphy and depositional environments. In: Ashton, N.M., Cook, J., Lewis, S.G., Rose, J. (Eds.), High Lodge: Excavations by G. de G. Sieveking, 1962-68, and J. Cook, 1988. British Museum Press, London, pp. 51-85.

Lewis, S.G., 1998. Quaternary Stratigraphy and Lower Palaeolithic Archaeology of the Lark Valley, Suffolk. In: Ashton, N.M., Healy, F., Pettitt, P. (Eds.), Stone Age Archaeology: Essays in Honour of John Wymer. Oxbow Books (Oxbow Monograph 102 \& Lithic Studies Society Occasional Paper No. 6), London, pp. 43-51.

Lewis, S.G., Rose, J., and Davies, H., 1999. Pre-Anglian fluvial and Anglian glaciogenic sediments, Knettishall, Suffolk, England. Proceedings of the Geologists' Association 110, 17-32.

Lewis, S.G., Whiteman, C.A., Preece, R.C. (Eds.), 2000. The Quaternary of Norfolk and Suffolk Field Guide. Quaternary Research Association, London.

Lhomme, V., 2007. Tools, space and behaviour in the Lower Palaeolithic: discoveries at Soucy in the Paris basin. Antiquity $81,536-554$. 
Loulergue, L., Schilt, A., Spahni, R., Masson-Delmotte, V., Blunier, T., Lemieux, B., Barnola, J-M., Raynaud, D., Stocker, T.F., Chappellaz, J., 2008. Orbital and millennial-scale features of atmospheric $\mathrm{CH}_{4}$ over the past 800,000 years. Nature 453, 383-386.

Machin, A.J., Hosfield, R.T., Mithen, S.J., 2007. Why are some handaxes symmetrical? Testing the influence of handaxe morphology on butchery effectiveness. Journal of Archaeological Science 34(6), 883-893.

MacRae, R.J., 1999. New Lower Palaeolithic Finds in Norfolk. Lithics: The Newsletter of the Lithic Studies Society 20, 3-9.

Maddy, D., Bridgland, D.R., 2000. Accelerated uplift resulting from Anglian glacioisostatic rebound in the Middle Thames Valley, UK?: evidence from the river terrace record. Quaternary Science Reviews 19, 1581-1588.

Maddy, D., Bridgland, D.R., Westaway, R., 2001. Uplift-driven valley incision and climate-controlled river terrace development in the Thames Valley, UK. Quaternary International 79, 23-36.

Mania, D., 1995. The earliest occupation of Europe: the Elbe-Saale region (Germany). In: Roebroeks, W., van Kolfschoten, T. (Eds.), The Earliest Occupation of Europe. Proceedings of the European Science Foundation Workshop at Tautavel (France) 1993. Leiden University Press, Leiden, pp. 85-101.

McNabb, J., 2007. The British Lower Palaeolithic: Stones in Contention. Routledge, Abingdon.

McNabb, J., Hosfield, R.T., 2009. Re-investigations of Lower Palaeolithic archaeology and deposits at Corfe Mullen. Proceedings of the Dorset Natural History \& Archaeological Society 130, 195198.

Mitchell, G.F., Penny, L.F., Shotton, F.W., West, R.G., 1973. A Correlation of Quaternary Deposits in the British Isles. Geological Society of London (Special Report No. 4). London.

Mithen, S.J., 1999. Imitation and cultural change: a view from the Stone Age, with specific reference to the manufacture of handaxes. In: Box, H.O., Gibson, K.R. (Eds.), Mammalian Social learning: Comparative and Ecological Approaches. Cambridge University Press, Cambridge, pp. 389-399.

O'Connor, A., 2007. Finding Time for the Old Stone Age: A History of Palaeolithic Archaeology and Quaternary Geology in Britain, 1860-1960. Oxford University Press, Oxford.

Oakley, K.P., Andrews, P., Keeley, L.H., Clark, J.D., 1977. A Reapprasial of the Clacton Spearpoint. Proceedings of the Prehistoric Society 43, 13-30.

Parfitt, S.A., 2005. A butchered bone from Norfolk: evidence for very early human presence in Britain. Archaeology International 8, 14-17.

Parfitt, S.A., 2008. Pakefield Cliffs: Archaeology and Palaeoenvironment of the Cromer Forest-bed Formation. In: Candy, I., Lee, J.R., Harrison, A.M. (Eds.), The Quaternary of Northern East Anglia Field Guide. Quaternary Research Association, London, pp. 130-136.

Parfitt, S.A., Barendregt, R.W., Breda, M., Candy, I., Collins, M.J., Coope, G.R., Durbridge, P., Field, M.H., Lee, J.R., Lister, A.M., Mutch, R., Penkman, K.E.H., Preece, R.C., Rose, J., Stringer, C.B., Symmons, R., Whittaker, J.E., Wymer, J.J., Stuart, A.J., 2005. The earliest record of human activity in northern Europe. Nature 438, 1008-1012.

Pawley, S.M., Bailey, R.M., Rose, J., Moorlock, B.S.P., Hamblin, R.J.O., Booth, S.J., Lee, J.R., 2008. Age limits on Middle Pleistocene glacial sediments from OSL dating, north Norfolk, UK. Quaternary Science Reviews 27, 1363-1377.

Peretto, C., 2006. The first peopling of southern Europe: the Italian case. C. R. Palevol 5, 283-290.

Pope, M., 2001. New investigations at Slindon Bottom Palaeolithic Site, West Sussex: an interim report. Lithics: Newsletter of the Lithic Studies Society 22, 3-10.

Pope, M., 2003. The earliest occupation of Sussex: recent research and future objectives. In: Rudling, D. (Ed.), The Archaeology of Sussex to AD 2000. Heritage Marketing and Publications Ltd., King's Lynn, pp. 17-28.

Pope, M., 2004. Behavioural implications of biface discard: assemblage variability and land-use at the Middle Pleistocene site of Boxgrove. In: Walker, E.A., Wenban-Smith, F.F., Healy, F. (Eds.), Lithics in Action: Papers from the Conference Lithic Studies in the Year 2000. Oxbow Books (Lithic Studies Society Occasional Paper No. 8), Oxford, pp. 38-47.

Pope, M., Roberts, M.B., 2005. Observations on the relationship between Palaeolithic individuals and artefact scatters at the Middle Pleistocene site of Boxgrove, UK. In: Gamble, C.S., Porr, M. (Eds.), The Hominid Individual in Context: Archaeological investigations of Lower and Middle Palaeolithic landscapes, locales and artefacts. Routledge, London, pp. 81-97.

Pope, M., Roberts, M.B., Maxted, A., Jones, P., 2009. The Valdoe: Archaeology of a Locality within the Boxgrove Palaeolandscape, East Sussex. Proceedings of the Prehistoric Society 75, 239-263. 
Powell, J.H., Glover, B.W., Waters, C.N., 2000. The Geology of the Birmingham Area. The Stationary Office (Memoir for the 1: 50000 Geological Sheet 168, England and Wales), London.

Preece, R.C. (Ed.), 1995. Island Britain: A Quaternary Perspective. Geological Society (Special Publication 96), London.

Preece, R.C., 2001. Molluscan evidence for differentiation of interglacials within the 'Cromerian Complex'. Quaternary Science Reviews 20, 1643-1656.

Preece, R.C., Gowlett, J.A.J., Parfitt, S.A., Bridgland, D.R., Lewis, S.G., 2006. Humans in the Hoxnian: habitat, context and fire use at Beeches Pit, West Stow, Suffolk, UK. Journal of Quaternary Science 21(5), 485-496.

Preece, R.C., Parfitt, S.A., 2008. The Cromer Forest-bed Formation: some recent developments relating to early human occupation and lowland glaciation In: Candy, I., Lee, J.R., Harrison, A.M. (Eds.), The Quaternary of Northern East Anglia Field Guide. Quaternary Research Association, London, pp. 60-83.

Preece, R.C., Parfitt, S.A., Coope, G.R., Penkman, K.E.H., Ponel, P., Whittaker, J.E., 2009. Biostratigraphic and aminostratigraphic constraints on the age of the Middle Pleistocene glacial succession in north Norfolk, UK. Journal of Quaternary Science 24(6), 557-580.

Proctor, C.J., Berridge, P.J., Bishop, M.J., Richards, D.A., Smart, P.L., 2005. Age of Middle Pleistocene fauna and Lower Palaeolithic industries from Kent's Cavern, Devon. Quaternary Science Reviews 24, 1243-1252.

Read, A., Godwin, M., Mills, C.A., Juby, C., Lee, J.R., Palmer, A.P., Candy, I., Rose, J., 2007. Evidence for Middle Pleistocene temperate-climate high sea-level and lowland-scale glaciation, Chapel Hill, Norwich, UK. Proceedings of the Geologists' Association 118, 143 156.

Roberts, M.B., Parfitt, S.A., 1999. Boxgrove: a Middle Pleistocene hominid site at Eartham Quarry, Boxgrove, West Sussex. English Heritage, London.

Roberts, M.B., Pope, M., in press. Mapping the early Middle Pleistocene deposits of the Slindon Formation, across the coastal plain of West Sussex and eastern Hampshire, UK. Left Coast Press, London.

Roberts, M.B., Stringer, C.B., Parfitt, S.A., 1994. A hominid tibia from Middle Pleistocene sediments at Boxgrove, UK. Nature 369(6478), 311-313.

Roberts, M.B., Gamble, C.S., Bridgland, D.R., 1995. The earliest occupation of Europe: the British Isles. In: Roebroeks, W., van Kolfschoten, T. (Eds.), The Earliest Occupation of Europe. Proceedings of the European Science Foundation Workshop at Tautavel (France) 1993. Leiden University Press, Leiden, pp. 165-191.

Roe, D.A., 1968. Gazetteer for British Lower and Middle Palaeolithic Sites. Council for British Archaeology, London.

Roe, D.A., 1981. The Lower and Middle Palaeolithic Periods in Britain. Routledge \& Kegan Paul, London.

Roe, D.A., 2001. Some Earlier Palaeolithic find-spots of interest in the Solent region. In: WenbanSmith, F.F., Hosfield, R.T. (Eds.), Palaeolithic Archaeology of the Solent River. Lithic Studies Society (Occasional Paper No. 7), London, pp. 47-56.

Roebroeks, W., 2001. Hominin behaviour and the earliest occupation of Europe: an exploration. Journal of Human Evolution 41, 437-461.

Roebroeks, W., 2005. Life on the Costa del Cromer. Nature 438, 921-922.

Roebroeks, W., 2006. The human colonisation of Europe: where are we? Journal of Quaternary Science 21(5), 425-435.

Roebroeks, W., Van Kolfschoten, T., 1994. The earliest occupation of Europe: a short chronology. Antiquity 68, 489-503.

Rose, J., 1987. Status of the Wolstonian glaciation in the British Quaternary. Quaternary Newsletter $53,1-9$.

Rose, J., 1994. Major river systems of central and southern Britain during the Early and Middle Pleistocene. Terra Nova 6, 435-443.

Rose, J., 2009. Early and Middle Pleistocene landscapes of eastern England. Proceedings of the Geologists' Association 120, 3-33.

Rose, J., Allen, P., 1977. Middle Pleistocene stratigraphy in south-east Suffolk. Journal of the Geological Society of London 133, 83-102.

Rose, J., Wymer, J.J., 1994. Record of a struck flake and the lithological composition of 'pre-glacial' river deposits at Hengrave, Suffolk, UK. Proceedings of the Suffolk Institute of Archaeology and History 38, 119-125. 
Rose, J., Whiteman, C.A., Allen, P., Kemp, R.A., 1999a. The Kesgrave Sands and Gravels: 'preglacial' Quaternary deposits of the River Thames in East Anglia and the Thames valley. Proceedings of the Geologists' Association 110, 93-116.

Rose, J., Lee J.A., Candy, I., Lewis S.G., 1999b. Early and Middle Pleistocene river systems in eastern England: evidence from Leet Hill, southern Norfolk, England. Journal of Quaternary Science 14, 347-360.

Rose, J., Moorlock, B.S.P., Hamblin, R.J.O., 2001. Pre-Anglian fluvial and coastal deposits in Eastern England: lithostratigraphy and palaeoenvironments. Quaternary International 79, 5-22.

Rowe, P.J., Atkinson, T.C., Turner, C., 1999. U-series dating of Hoxnian interglacial deposits at Marks Tey, Essex, England. Journal of Quaternary Science 14, 693-702.

Saville, A., 1988. The Waite Collection of Palaeolithic quartzites from the Nuneaton area of Warwickshire. In: MacRae, R.J., Moloney, N. (Eds.), Non-Flint Stone Tools and the Palaeolithic Occupation of Britain. BAR (British Series No. 189), Oxford, pp. 67-88.

Schreve, D.C., 2001. Differentiation of the British late Middle Pleistocene interglacials: the evidence from mammalian biostratigraphy. Quaternary Science Reviews 20, 1693-1705.

Schreve, D., Currant, A., Stringer, C., 1999. Conclusions: correlation of the Westbury Cave deposits, In: Andrews, P., Cook, J., Currant, A., Stringer, C.B. (Eds.), Westbury Cave: The Natural History Museum Excavations 1976-1984. Western Academic and Specialist Press, Bristol, pp. 275-284.

Scott, G.R., Gibert, L., 2009. The oldest hand-axes in Europe. Nature 461, 82-85.

Shotton, F.W., 1930. Palaeolithic implements found near Coventry. Proceedings of the Prehistoric Society of East Anglia 6(3), 174-181.

Shotton, F.W., 1988. The Wolstonian geology of Warwickshire in relation to Lower Palaeolithic surface finds in North Warwickshire. In: MacRae, R.J., Moloney, N. (Eds.), Non-Flint Stone Tools and the Palaeolithic Occupation of Britain. BAR (British Series No. 189), Oxford, pp. 89-94.

Shotton, F.W., Keen, D.H., Coope, G.R., Currant, A.P., Gibbard, P.L., Aalto, M., Peglar, S.M., Robinson, J.E., 1993. The Middle Pleistocene Deposits of Waverley Wood Pit, Warwickshire, England. Journal of Quaternary Science 8(4), 293-325.

Smith, A.J., 1985. A catastrophic origin for the palaeovalley system of the eastern English Channel. Marine Geology 64, 65-75.

Solomon, J.D., 1933. The implementiferous gravels of Warren Hill. The Journal of the Royal Anthropological Institute of Great Britain and Ireland 63, 101-110.

Stephens, M., Cooper, L., Hopkinson, T., 2006. The Waite Collection, Historic Environment Record and Pleistocene fauna of Leicestershire: A Critical Assessment by the National Ice Age Network. Transactions of the Leicestershire Archaeological and Historical Society 80, 191195.

Stephens, M., Challis, K., Graf, A., Howard, A.J., Rose, J., Schreve, D.C., 2008. New exposures of Bytham River deposits at Brooksby, Leicestershire, UK: context and importance. Quaternary Newsletter 115, 14-27.

Straw, A., 1996. The Quaternary record of Kent's Cavern — a brief reminder and update. Quaternary Newsletter 80, 17-25.

Stringer, C.B., 2006. Homo Britannicus: The Incredible Story of Human Life in Britain. Penguin Books, London.

Stuart, A.J., 1992. The High Lodge mammalian fauna. In: Ashton, N.M., Cook, J., Lewis, S.G., Rose, J. (Eds.), High Lodge: Excavations by G. de G. Sieveking, 1962-68, and J. Cook, 1988. British Museum Press, London, pp. 120-123.

Stuart, A.J., Lister, A.M., 2001. The mammalian faunas of Pakefield/Kessingland and Corton, Suffolk, UK: evidence for a new temperate episode in the British early Middle Pleistocene. Quaternary Science Reviews 20, 1677-1692.

Stuart, A.J., West, R.G., 1976. Late Cromerian fauna and flora at Ostend, Norfolk. Geological Magazine 113, 469-473.

Sumbler, M.G., 1995. The terraces of the rivers Thame and Thames and their bearing on the chronology of glaciation in central and eastern England. Proceedings of the Geologists' Association 106, 93-106.

Sumbler, M.G., 2001. The Moreton Drift: a further clue to glacial chronology in central England. Proceedings of the Geologists' Association 112, 13-27.

Thieme, H., 2005. The Lower Palaeolithic art of hunting: the case of Schöningen 13 II-4, Lower Saxony, Germany. In: Gamble, C.S., Porr, M. (Eds.), The Hominid Individual in Context: 
Archaeological investigations of Lower and Middle Palaeolithic landscapes, locales and artefacts. Routledge, London, pp. 115-132.

Villa, P., 2001. Early Italy and the colonization of Western Europe. Quaternary International 75, 113130.

Voinchet, P., Despriée, J., Tissoux, H., Falguères, C., Bahain, J-J., Gageonnet, R., Dépont, J., Dolo, J.-M., in press. ESR chronology of alluvial deposits and first human settlements of the Middle Loire Basin (Region Centre, France). Quaternary Geochronology.

Warren, S.H., 1911. On a Palaeolithic (?) Wooden Spear. The Quarterly Journal of the Geological Society of London 67, xcix.

Wessex Archaeology, 1993. The Southern Rivers Palaeolithic Project. Report No. 1. 1991-1992. The Upper Thames Valley, the Kennett Valley and the Upper Solent Drainage System. Wessex Archaeology \& English Heritage, Salisbury.

Wessex Archaeology, 1994. The Southern Rivers Palaeolithic Project. Report No. 3. 1993-1994. The Sussex Raised Beaches and the Bristol Avon. Wessex Archaeology \& English Heritage, Salisbury.

Wessex Archaeology, 1996a. The English Rivers Palaeolithic Project. Report No. 5. 1994-1995. The Thames Valley and the Warwickshire Avon. Wessex Archaeology \& English Heritage, Salisbury.

Wessex Archaeology, 1996b. The English Rivers Palaeolithic Project. Report No. 2. 1994-1995. The Great Ouse Drainage, Yorkshire, and the Lincolnshire Wolds. Wessex Archaeology \& English Heritage, Salisbury.

Wessex Archaeology, 1997. The English Rivers Palaeolithic Project. Report No. 3. 1996-1997. East Anglia Rivers and the Trent Drainage. Wessex Archaeology \& English Heritage, Salisbury.

Westaway, R., 2009. Quaternary vertical crustal motion and drainage evolution in East Anglia and adjoining parts of southern England: chronology of the Ingham River terrace deposits. Boreas 38, 261-284.

Westaway, R., Bridgland, D.R., White, M.J., 2006. The Quaternary uplift history of central southern England: evidence from the terraces of the Solent River system and nearby raised beaches. Quaternary Science Reviews 25, 2212-2250.

White, M.J., 1998. On the significance of Acheulean biface variability in southern Britain. Proceedings of the Prehistoric Society $64,15-44$.

White, M.J., 2006. Things to do in Doggerland when you're dead: surviving OIS3 at the northwesternmost fringe of Middle Palaeolithic Europe. World Archaeology 38(4), 547-575.

White, T.S., Bridgland, D.R., Howard, A.J., White, M.J., 2008. Lower Palaeolithic quartzite artefacts from the Trent Valley at East Leake, Nottinghamshire (SK 558248): new light on a hidden resource. Quaternary Newsletter 114, 10-20.

Whiteman, C.A., 1992. The palaeogeography and correlation of pre-Anglian-Glaciation terraces of the River Thames in Essex and the London Basin. Proceedings of the Geologists' Association 103(1), 37-56.

Whiteman, C.A., Rose, J., 1992. Thames river sediments of the British Early and Middle Pleistocene. Quaternary Science Reviews 11, 363-375.

Woodcock, A., 1981. The Lower and Middle Palaeolithic Periods in Sussex. BAR (British Series No. 94), Oxford.

Wymer, J.J., 1985. Lower Palaeolithic sites in East Anglia. Geo Books, Norwich.

Wymer, J.J., 1988. Palaeolithic archaeology and the British Quaternary sequence. Quaternary Science Reviews 7, 79-98.

Wymer, J.J., 1999. The Lower Palaeolithic Occupation of Britain. Wessex Archaeology \& English Heritage, Salisbury.

Wymer, J.J., 2001. Palaeoliths in a lost pre-Anglian landscape. In: Milliken, S., Cook, J. (Eds.), A Very Remote Period Indeed. Oxbow Books, Oxford, pp. 174-179.

Wymer, J.J., Lewis, S.G., Bridgland, D.R., 1991. Warren Hill, Mildenhall, Suffolk (TL 744743). In: Lewis, S.G., Whiteman, C.A., Bridgland, D.R. (Eds.), Central East Anglia and the Fen Basin: Field Guide. Quaternary Research Association, London, pp. 50-58. 
Figure 1: Key southern British rivers and Lower Palaeolithic sites of the early Middle Pleistocene (after Gibbard, 1995, Fig. 2; Wymer, 1999, Fig. 67, Maps 43 and 46; McNabb, 2007, Fig. 4.1; Rose, 2009, Figs. 8 and 12). The early Middle Pleistocene coastline reconstruction for north-east Norfolk follows Rose (2009, Fig. 8c). The course of the modern River Trent (after Howard et al., 2007, Fig. 1) is shown given the lack of pre-MIS 12 evidence (see text).

Figure 2: British early Middle Pleistocene sites in the Bytham River and Ancaster River landscape of East Anglia and the Midlands. The Bytham and Ancaster rivers' routes, the extents of the Bytham Sands and Gravels, and the Happisburgh (MIS 16) glaciation (Hamblin et al., 2005) flow directions and extents after Rose et al. (1999, Fig. 1) and Rose (2009, Figs. 3, 8 and 17). Sites after Wymer (1999, Maps 42, 43 and 54) and McNabb (2007, Fig. 4.1). 1: Brandon Fields; 2: Feltwell (Frimstone Quarry); 3: Feltwell (Shrub Hill); 4: Hengrave; 5: High Lodge; 6: Hockwold-cum-Wilton (Wilton Hill); 7: Icklingham (Rampart Fields); 8: Ingham; 9: Lakenheath (Maidscross Hill); 10: Leet Hill; 11: Timworth; 12: Warren Hill; 13: Wolvey-Bramcote-Burton Hastings (Waite Collection); 14: Charnwood Forest.

Figure 3: British early Middle Pleistocene sites in the River Thames landscape. The River Thames' route and the extents of the Kesgrave Sands and Gravels (Colchester Formation) after Rose et al. (1999, Fig. 1) and Rose (2009, Fig. 8). Sites after Bridgland (1994, Fig. 3.1 and 5.1), Gibbard (1979, Fig. 1) and Wymer (1999, Maps 3, 14, 53). 1: Ardleigh; 2: Farnham (Terrace A sites); 3: St. George's Hill (Weybridge); 4: Tilehurst (Gerrard's Cross Terrace sites); 5: Wallingford Fan Gravels; 6: Wivenhoe.

Figure 4: British early Middle Pleistocene sites in the Solent River and West Sussex Upper Coastal Plain landscapes. The Solent River's routes and the distribution of the Westbourne-Arundel raised beach after Westaway et al. (2006, Fig. 2) and Pope et al. (2009, Fig. 1). The Solent tributaries' routes are especially uncertain in their upper reaches due to poor terrace preservation and the figure reflects modern courses and younger terrace deposits in these areas. The confluences of the Stour/Avon and the Test/ltchen with the Solent River are estimated from the location of the Solent River's Setley Plain (western Solent) terrace gravels (of probable MIS 12 or 13 age, see text for details). Sites after Wymer (1999, Maps 23, 25, 30 and 46) and Pope et al. (2009, Fig. 1). 1: Boxgrove (Amey's Eartham Pit); 2: Brockenhurst (Setley Plain Pits); 3: Corfe Mullen Gravel Pits; 4: East Lavant; 5: Poole (Foxholes); 6: Ringwood (Crow Hill, Hightown Hill, Rockford Common); 7: Romsey (Pauncefoot Hill and Ridge Gravel Pits); 8: Slindon; 9: Valdoe Quarry.

Figure 5: Flake tools from High Lodge (after Ashton et al., 1992a, Figs. 11.15(3), 11.17(7), 11.18(1), 11.20(4), and Plate 30; (c) British Museum Press): flaked flake (a) and Clactonian notches (b), denticulate (c), scraper with minimal edge modification (d), 'classic' scrapers (e). The quality of the invasive flaking on the retouched scraper edges (indicated on figure) led Evans (1897, 548-549) to liken the finest of the 'classic' High Lodge scrapers to those found at the Mousterian type-site of Le Moustier: see Ashton and McNabb, 1992 for further details).

Figure 6: Quartzite artefacts (a: biface; b and c: bifacial choppers) from Bytham River deposits at Frimstone Quarry, Feltwell (Hardaker and MacRae, 2000, Fig. 2; @ Terry Hardaker and R.J. MacRae, and the Lithic Studies Society)

Figure 7: Ovate ( $a$ and b) and limande (c) Boxgrove bifaces from site Q1/B, Unit 4c (the Slindon Soil Bed); with examples of tranchet flaking indicated (after Roberts and Parfitt, 1999, Fig. 249; @ English Heritage)

Figure 8: Cortex-retaining bifaces from the breccia deposit, Kent's Cavern (after Roe, 1981, Fig. 4:4; (c) D.A. Roe, and Routledge and Kegan Paul) 
Table 1: early Middle Pleistocene (MIS 19-12) sites and findspots in Britain, by region (Figures 1-4). Uncertain age assignments are indicated in italics. Where contrasting age estimates have been proposed, sites are listed against the differing MIS. Sites after Wessex Archaeology (1993, 1994, 1996a, 1996b, 1997), Wymer (1985, 1999), and McNabb (2007). Ages after Gibbard (1979, 1982), Ashton et al. (1992a), Shotton et al. (1993), Bridgland (1994), Andrews et al. (1999), Roberts and Parfitt (1999), Rose et al. (1999a), Maddy et al. (2001), Lee et al. (2004a), Parfitt et al. (2005), Keen et al. (2006), Westaway et al. (2006), Preece and Parfitt (2008), Preece et al. (2009), Pope et al. (2009), and Ashton and Hosfield (2010). 'G: Glacial; I: Interglacial. MIS boundaries after Bassinot et al. (1994). ${ }^{2}$ Contrasting ages for the Bytham River terraces (and sites) are summarised in Tables 2 and 4 and the text. ${ }^{3}$ Although the full age range is given for MIS 12 , the paper only considers archaeological material of early MIS 12 age. ${ }^{4}$ Contrasting interpretations for the age of the Happisburgh 1 site are summarised in Table 2 and the text.

Table 2: Summary of key arguments for the 'new glacial stratigraphy' and 'biostratigraphic age' models for the Middle Pleistocene glacial succession in Norfolk. The vertical order of Formations is stratigraphically correct: e.g. the deposits of the Sidestrand Cliff Formation (= Trimingham lake bed) overlie the youngest glacial outwash of the Sheringham Cliff's Formation (Preece et al., 2009). ${ }^{1}$ An MIS 12 age for the Lowestoft Till is agreed by both models (see text for details). See Lee et al. (2004a, 2004b, 2006a), Hamblin et al. (2005), Preece and Parfitt (2008), Rose (2009), Preece et al. (2009), and other sources cited in the table for full details and discussion.

Table 3: Sequences at key British early Middle Pleistocene archaeological sites (after Ashton et al., 1992a; Roberts and Parfitt, 1999; Shotton et al., 1993; Lee et al., 2004a, 2006a; Parfitt et al., 2005; Keen et al., 2006; Gibbard et al., 2008) and selected terrace units for the Thames (after Gibbard, 1979, 1982; Bridgland, 1994; Maddy et al., 2001). The Solent River terraces are not listed due to age uncertainties and the difficulties of correlating between the Solent River and its tributaries (Allen and Gibbard, 1993; Westaway et al., 2006; Ashton and Hosfield, in press). Members marked ${ }^{* \star}$ contain archaeology. The differing interpretations of the Happisburgh sequence are summarised in Table 2. ${ }^{1}$ The High Lodge Clayey-Silts and High Lodge Sands are of pre-MIS 12 age, but were glacially transported and inter-bedded with the Mildenhall Lower Diamicton (Ashton et al., 1992a). ${ }^{2}$ After Gibbard et al. (2008). ${ }^{3}$ After Lee et al. (2004a, 2006a). ${ }^{4}$ Prior to Lee et al. (2004a, 2006a) the Cromer Forest-bed Formation deposits at Pakefield (including Mimomys) were assigned an age from an early phase of the early Middle Pleistocene on biostratigraphical grounds, although the site was suggested to be younger than the West Runton Freshwater Bed (Preece, 2001; Stuart and Lister, 2001). Parfitt et al. (2005) suggest an age for Pakefield of either MIS 19 or MIS 17 (see text for details). ${ }^{5}$ The Waverley Wood Baginton Formation is assigned to MIS 13 (based on an MIS 12 age for the overlying Thrussington Member), although Preece et al. (2009) have argued that AAR data suggests either an MIS 13 or 15 age. ${ }^{6}$ Only early MIS 12 Thames terraces are listed, although later MIS 12 terraces (e.g. the Black Park Terrace) also occur (Gibbard, 1985; Bridgland, 1994; Maddy et al., 2001). ${ }^{7}$ Terrace A at Alice Holt, Farnham is argued by Gibbard (1982) to potentially be equivalent to the MIS 12 Warren Heath Gravel.

Table 4: Terrace and restricted MIS assignments for selected Bytham River deposit exposures and Lower Palaeolithic sites and findspots (after Lewis, 1998; Lee et al., 2004a). The MIS estimates for the Lee et al. (2004) model are not inferred for the Lewis (1998) model. Archaeological sites are highlighted in bold. Sites with uncertain archaeological (artefact) evidence are highlighted in italics. ${ }^{1}$ The specific sites at the locations of Lakenheath (Maidscross Hill?), Brandon (Brandon Fields?), and Feltwell (Shrub Hill Farm? Frimstone Quarry?) are not listed in Lee et al. (2004a).

Table 5: Summary of palaeoenvironmental evidence for Boxgrove, Happisburgh 1, High Lodge, Pakefield, and Waverley Wood (Coope, 1992; Hunt, 1992; Lewis, 1992; Stuart, 1992; Shotton et al., 1993; Roberts and Parfitt, 1999; Stuart and Lister, 2001; Coope, 2006; Candy et al., 2006; Ashton et al., 2008; Holmes et al., in press). ${ }^{1}$ The Boxgrove temperature estimates are based on ostracod and herpetofauna assemblages from the Slindon Soil Bed or its temporal correlatives in the freshwater pond sequence. ${ }^{2}$ Present day British temperatures (1971-2000 averages for Southern England): Coldest month (January): $1.4-7.0^{\circ} \mathrm{C}$; Warmest month (July): $11.7-21.3^{\circ} \mathrm{C}$. Source:

http://www.metoffice.gov.uk/. ${ }^{3}$ Temperature estimates calculated from coleoptera (C), herpetofauna $(\mathrm{H})$, molluscs $(\mathrm{M})$, or ostracods/herpetofauna combined $(\mathrm{O}+\mathrm{H})$. 
Table 6: Palaeo-climate estimates for southern European (Spanish) Early Pleistocene and early Middle Pleistocene sites, and British early Middle Pleistocene sites. Southern European (Spanish) site data from Agusti et al. (2009). British site chronological data after Ashton et al. (1992a), Shotton et al. (1993), Lee et al. (2004a), Parfitt et al. (2005), Keen et al. (2006), and Preece et al. (2009). British site temperature data after Coope (2006), and Holmes et al. (in press). ${ }^{1}$ Southern European (Spanish) site data generated using the Mutual Climatic Range (MCR) method on paleoherpetological faunas. ${ }^{2}$ Site lacking evidence of a hominin presence, included for comparison. ${ }^{3}$ British data generated using the MCR method on insect fauna (Coope 2006; with the exception of Boxgrove). ${ }^{4}$ Boxgrove data generated using the MCR method on herpetofauna and the Mutual Ostracod Temperature Range (MOTR) method on ostracods (Holmes et al. in press). 